\title{
PENGARUH ASSESMEN PORTOFOLIO DAN USIA TERHADAP PENING- KATAN KEMAMPUAN KEAKSARAAN BAGI WARGA BELAJAR KEAK- SARAAN FUNGSIONAL
}

\begin{abstract}
Abdul Kahar*
Abstract

The objective of the research is to know the differences in reading and writing achievement between non-formal participants with conventional evaluation and those with portfolio evaluation treatment and between those of 15 years age or under and those of above 15 years age or above, and the interaction type of evaluation and age variable. The design of this research used Factorial Experiment 2X2. Research population covered all of those who learnt at Community Learning Activities Center in Makassar. Eighty respondents were selected by multi stage random sampling. Data on reading and writing learning achievement were obtained using a test and analyzed using descriptive statistic analysis and inferential analysis with Multivariate Analysis of Variants (two-way MANOVA). The research conducted in 2005 indicates that there are significant differences in reading and writing achievement between non-formal participants with conventional evaluation and those with portfolio evaluation treatment and between those of 15 years age or under and those of above 15 years age or above. These findings imply that in implementing functional literacy program, the application of different evaluation models to different age group need to be considered.
\end{abstract}

Keywords: evaluation, portofolio evaluation, conventional evaluation, age, learning perspective

\begin{abstract}
Abstrak
Penelitian ini bertujuan mengetahui perbedaan hasil belajar dalam membaca dan menulis antara (a) peserta pendidikan nonformal dengan penilaian konvensional dan dengan penilaian portofolio, dan (b) mereka yang berumur 15 tahun atau kurang dan yang berumur di atas 15 tahun. Di samping itu, juga ingin diketahui jenis interaksi evaluasi serta variable umur. Desain penelitian menggunakan Eksperimen Faktorial $2 \times 2$. Populasi penelitian mencakup semua warga belajar di Pusat Kegiatan Belajar Masyarakat (PKBM) di Makasar dan sebagai responden dipilih 80 warga pelajar dengan teknik multi stage random sampling. Data hasil belajar membaca dan menulis diperoleh dengan menggunakan tes dan dianalisis dengan menggunakan analisis statistic deskriptif dan analisis inferensial dengan Multivariate Analysis of Variants (two-way MANOVA). Hasil penelitian menunjukkan bahwa terdapat perbedaan hasil belajar yang signifikan dalam membaca dan menulis antara (a) peserta pendidikan nonformal dengan penilaian konvensional dan dengan penilaian portofolio, dan (b) mereka yang berumur 15 tahun atau kurang dan yang berumur di atas 15 tahun. Implikasi hasil penelitian ini ialah dalam menyelenggarakan program keaksaraan fungsional, penerapan model evaluasi yang.berbeda untuk kelompok umur yang berbeda perlu dipertimbangkan.
\end{abstract}

Kata-kata kunci: penilaian, penilaian portofolio, penilaian konvensional, usia, perspektif belajar

\section{PENDAHULUAN}

\section{Latar Belakang}

Kebijakan pemerintah dalam peningkatan program pemberantasan buta aksara merupakan komitmen bersama semua bangsa-bangsa yang dicetuskan dalam kesepakatan Dakar, yaitu tercapainya peningkatan sebesar 50 persen pada tingkat keaksa-raan

${ }^{*}$ Alumni Program Doktor Pasca Sarjana UNJ orang dewasa terutama perempuan pada tahun 2015 dan akses yang sama terhadap pendidikan dasar dan pendidikan berkelanjutan bagi semua orang dewasa.

Menyadari demikian pentingnya upaya pemberantasan buta aksara dalam peningkatan mutu sumber daya manusia, Pemerintah Indonesia melalui Direktorat Jenderal Pendidikan Nonformal dan Informal, bertekad mewujudkan kesepakatan pengentasan 
masalah buta aksara dengan cara meningkatkan kualitas dan perluasan penyelenggaraan pendidikan keaksaraan. Sebagai upaya mewujudkan kesepakatan itu, Rencana Pembangunan Jangka Menengah 2004-2009 telah menargetkan penurunan penduduk buta aksara usia 15 tahun ke atas sebanyak 1,6 juta per tahun sehingga diharapkan pada 2009 ini tersisa sekitar 7 juta atau sekitar 5 persen, sehingga enam tahun lebih cepat dari target Dakar. Pada tahun 2015, buta aksara di Indonesia diharapkan menjadi nol persen (http://www.depdiknas.go.id).

Direktorat Pendidikan Masyarakat, dengan gencarnya mengkampanyekan gerakan percepatan pemberantasan buta aksara dengan membangun komitmen bersama antara pemerintah pusat dan daerah, namun penurunan empat tahun terakhir belum berpengaruh secara positif terhadap peringkat Indonesia dalam Indeks Pembangunan Manusia yaitu masih pada posisi 107 dari tahun 2005 (UNDP, Human Development Report 2007/2008).

Program pemberantasan buta aksara pada dasarnya diselenggarakan untuk membantu warga belajar meningkatkan taraf hidupnya. Oleh karena itu pendekatan belajar yang digunakan dalam membelajarkan warga belajar hendaknya dapat membantu mereka dalam memecahkan masalah yang dihadapi dalam kehidupannya sehari-hari, atau dengan kata lain harus fungsional artinya punya nilai manfaat pada dirinya dalam kehidupan sehari-hari.

Penilaian merupakan suatu hal yang sangat penting dalam suatu proses pembelajaran. Hal ini dimaksudkan untuk mengetahui apakah suatu program pembelajaran keaksaraan tersebut telah dikuasai oleh warga belajar atau belum. Penilaian keaksaraan fungsional selama ini menggunakan penilaian dalam bentuk tes formatif dan sumatif saja. Hal ini kurang relevan dengan kondisi warga belajar orang dewasa, karena orang dewasa yang sudah kaya dengan pengalaman tidak mau diketahui kekurangannya, sehingga penilaian yang bersifat tes, bagi orang dewasa tidak tepat. Kondisi ini dibuktikan dengan sebuah penelitian kualitatif yang dilaksanakan oleh Centre for Human Capacity Development (CHCD) menemukan suatu fenomena di lapangan bahwa "hampir semua kelompok belajar keaksaraan fungsional tidak pernah mengadakan penilaian akhir. Salah satu penyebab sulitnya dilaksanakan penilaian dikarenakan setiap akan dilaksanakan tes hasil belajar, maka warga belajar cenderung tidak hadir pada pembelajaran".

Melihat kenyataan tersebut, maka sistem penilaian hasil belajar keaksaraan perlu dicarikan model penilaian yang sesuai dengan karakteristik pembelajaran orang dewasa dan lebih bersifat komprehensif namun tidak terkesan menguji atau mengetes kemampuan warga belajar yaitu dengan model penilaian portofolio.

Program pendidikan keaksaraan yang sebagian besar peserta adalah orang dewasa, maka isi kurikulum tidak hanya semata-mata mengembangkan kemampuan keaksaraan, tetapi juga mengembangkan keterampilan fungsional yang dapat memecahkan masalah yang ditemui dalam kehidupan sehari-hari. Atas dasar itu, materi kurikulum pendidikan keaksaraan tidak seperti yang dipakai anak-anak sekolah, tetapi isinya memperhatikan karakteristik orang dewasa karena orang dewasa mempunyai kemampuan berpikir analisis dan mempunyai sekumpulan pengetahuan sebagai pengalaman hidupnya.

Berkaitan dengan kemampuan yang diperoleh sebagai hasil belajar, Horward Kingsley seperti dikutip oleh Sudjana (1999) membagi tiga bentuk hasil belajar, yakni (1) keterampilan dan kebiasaan, (2) pengetahuan dan pengertian, (3) sikap dan cita-cita. Adapun Gagne membagi hasil belajar dalam lima kategori yaitu: (1) informasi verbal, yaitu kemampuan individu untuk menyatakan kembali informasi yang diperoleh dari proses belajar dalam bentuk bahasa, baik lisan maupun tulisan, (2) keterampilan intelektual yaitu kemampuan yang dimiliki seseorang untuk membedakan, mengabstraksikan suatu obyek, menghubung-hubungkan konsep dan dapat mensghasilkan suatu pengertian, memecahkan suatu persoalan, (3) strategi kognitif, yaitu kemampuan seseorang untuk mengatur dan mengarahkan aktivitas mentalnya sendiri dalam memecahkan masalah yang dihadapinya, (4) sikap adalah kemampuan yang dimiliki seseorang berupa kecenderungan untuk menerima atau menolak suatu obyek berdasarkan penilaian atas obyek tersebut, (5) keterampilan motorik, berupa kemampuan seseorang untuk melakukan serangkaian gerakan jasmani dari anggota badan secara terpadu dan terkoordinasi,

Selanjutnya, Bloom dkk. (1987) membagi dimensi hasil belajar dalam tiga ranah atau kawasan yakni: (1) ranah kognitif, (2) ranah afektif, dan (3) ranah psikomotor. Ranah kognitif berkenan dengan hasil belajar intelektual yang meliputi enam aspek yakni; (a) pengetahuan atau ingatan, (b) pemahaman, (c) aplikasi, (d) analisis, (e) sintesis, dan (f) evaluasi. Kedua aspek pertama, yakni pengetahuan, pemahaman biasanya digolongkan sebagai tingkat kognitif rendah, sedangkan keempat aspek lainnya, yakni aplikasi, analisis, sintesis, dan evaluasi sering disebut sebagai kognitif tingkat tinggi. Ranah afektif berkenan dengan sikap yang terdiri dari lima aspek yakni; (a) penerimaan, (b) jawaban atau reaksi, (c) penilaian, (d) organ- 
isasi, dan (e) internalisasi. Terakhir ranah psikomotor yang berkenan dengan hasil belajar keterampilan dan kemampuan bertindak yang terdiri dari enam aspek, yakni; (a) gerakan refleks, (b) keterampilan gerakan dasar, (c) kemampuan perseptual, (d) keharmonisan atau ketepatan, (e) gerakan keterampilan kompleks, dan (f) gerakan ekspresif dan interpretatif.

Berdasarkan uraian-uraian di atas maka dapat dikatakan bahwa yang dimaksud dengan hasil belajar dalam penelitian ini adalah kemampuan yang dicapai oleh warga belajar dalam aspek pengetahuan, pemahaman, aplikasi, analisis, sintesis dan evaluasi setelah warga selesai mengikuti proses pembelajaran keaksaraan (membaca dan menulis) dalam suatu penggalan waktu tertentu.

Peningkatan kemampuan membaca dan menulis warga belajar adalah salah satu upaya yang dilaksanakan dalam proses pembelajaran keaksaraan fungsional untuk mencapai tujuan yang telah ditetapkan. Namun pada kenyataannya hal tersebut sangat sulit dicapai, hal ini disebabkan dengan keunikan dan karakteristik orang dewasa dalam belajar. Kemampuan membaca dan menulis seringkali tidak dapat terukur dalam proses pembelajaran yang dilaksanakan, mengingat pelaksanaan penilaian kemampuan warga belajar tidak dilaksanakan sesuai dengan karakteristik warga belajar.

Proses pembelajaran keaksaraan fungsional, membaca adalah salah satu strategi pembelajaran yang dilakukan dalam rangka memberantas kebutaaksaraan warga belajar. Strategi ini merupakan salah satu tolok ukur kemampuan yang harus dikuasai warga belajar dalam pemberantasan buta aksara. Strategi-strategi pembelajaran keaksaraan fungsional dikenal dengan istilah "Calistungdasi", yaitu; 1) membaca; 2) menulis; 3) berhitung; 4) diskusi, dan 5) aksi.

Membaca menurut Montessori adalah bahasa yang ditulis. Membelajarkan membaca pada orang dewasa berbeda dengan anak-anak, karena mereka sudah punya sikap hidup, pengalaman hidup, pandangan terhadap nilai-nilai hidup, minat, kebutuhan, ide/gagasan, hasrat-hasrat dan dorongan-dorongan untuk melakukan suatu perbuatan. Atas dasar itu membelajarkan membaca pada mereka harus dimulai dari hal-hal di atas, bukan dimulai dari pengenalan dan menghafal huruf-huruf/abjad A - Z. Belajar membaca untuk orang dewasa dimulai dari sesuatu yang bermakna, terdekat, dan melekat dengan dirinya, kemudian meluas dan melebar dari tahapan yang satu ke tahapan berikutnya seperti lingkaran spiral. Sesuatu yang bermakna dan melekat pada warga belajar adalah :"nama diri", meskipun mereka buta aksara tetapi untuk melafalkan nama dirinya dijamin bisa. Bahwa "nama diri" itu terdiri atas lambang-lambang huruf berupa konsonan dan vokal atau rangkaian huruf, bagi mereka mungkin tidak memahami. Alasannya sederhana, kita yang sudah melek aksara pun jika ditanya huruf A, B, dan seterusnya, jika tidak dirangkaikan dalam bentuk kata, huruf-huruf tersebut tidak mempunyai makna/arti.

Mengingat orang dewasa akan lebih cepat dan lebih mudah menerima dan memahami isi bacaan, apabila ia telah menyadari dan menginsafi manfaat dan pentingnya membaca bagi kehidupan, maka dalam pembelajaran membaca bagi warga belajar para tutor senantiasa memperhatikan hal itu. Sebagaimana contoh, ketika seorang warga belajar menyadari dan menginsafi manfaat air bagi kehidupan sehari-hari, maka mereka akan lebih cepat menerima dan memahami apabila mereka dibelajarkan dengan masalah air dan hal-hal yang melingkupinya.

Untuk menjamin agar pengetahuan/informasi/ materi bacaan dapat segera dipahami oleh warga belajar, maka prinsip-prinsip materi yang dibaca harus memperhatikan: (a) materi bacaan hendaknya dipusatkan pada masalah nyata dan mendesak bagi warga belajar dan masyarakatnya, (b) materi bacaan hendaknya menunjukkan masalah atau menguraikan keadaan masalah potensial, dan memberikan informasi teknis terkait dengan masalah di atas, (c) materi bacaan hendaknya disajikan dalam suasana yang memungkinkan terjadinya proses diskusi lebih lanjut, dan berbagi pengalaman antar sesama warga belajar dan tutor, (d) materi bacaan menggunakan kata-kata sederhana, konkret, dan mudah dipahami oleh warga belajar, (e) materi bacaan dimulai dari struktur yang sederhana (kata, kalimat) menuju ke hal-hal yang sulit, dan (f) materi bacaan hendaknya menggunakan kalimat yang tidak terlalu panjang (3-7 kata), dan apabila memungkinkan gunakan kata-kata dasar terlebih dahulu sebelum beranjak ke kata-kata yang kompleks dan memiliki makna ganda.

Membaca dan menulis adalah dua hal yang tidak dapat di pisahkan, seseorang menulis sudah barang tentu di dalamnya ada unsur membaca, namun warga belajar keaksaraan fungsional yang dominan orang dewasa, tidak jarang dijumpai punya kemampuan menulis tapi tidak dapat membaca. Demikian juga sebaliknya, punya kemampuan membaca tapi tidak dapat menulis.

Sebagai salah satu keterampilan berbahasa, menulis merupakan keterampilan yang sukar dan kompleks. Dikatakan sukar dan kompleks, banyak warga belajar tidak mampu menulis dengan baik. Ketidakmampuan menulis dengan baik itu disebabkan 
warga belajar tidak dapat menyusun kalimat dengan baik dan benar, kurangnya kemampuan kosa kata atau ketidakmampuan menentukan kapan mereka harus menulis dan apa yang menjadi ide pokok dalam penulisannya.

Karsana mengungkapkan bahwa pada hakekatnya menulis adalah pengutaraan sesuatu dengan menggunakan bahasa secara tertulis. Dengan mengutarakan sesuatu itu dimaksudkan menyampai-kan, memberitakan, menceriterakan, melukiskan, menerangkan, meyakinkan, menjelmakan, dan sebagainya kepada pembaca agar mereka memahami apa yang terjadi pada suatu peristiwa atau suatu kegiatan.

Jadi, yang dimaksud menulis adalah suatu keterampilan berbahasa yang bertujuan untuk memberikan segala bentuk informasi tertulis dari penulis kepada pembaca. Proses pemberian dan penerimaan informasi harus didasarkan pada adanya pemahaman bahasa yang digunakan penulis untuk diserap atau diterima pembaca. Dapat saja terjadi bahwa pembaca bukan penutur bahasa yang digunakan dalam bacaan, tetapi ia memahami bahasa bacaan itu. Dapat pula seorang penulis menuangkan buah pikirannya ke dalam bahasa yang dalam sehari-harinya bukan bahasanya sendiri, dan pembaca pun juga demikian. Semua pemakaian bahasa bertumpu pada pemahaman terhadap bahasa bacaan.

Sehubungan dengan hal di atas, Avelrod dan Copper menyatakan bahwa menulis merupakan suatu proses penemuan yang komplek dan merupakan keterampilan yang membuat seseorang dapat belajar mengatur waktu. Menulis merupakan suatu refleksi dalam diri seseorang yang tumbuh melalui suatu proses. Seseorang dapat menulis dengan baik, tentunya telah melalui berbagai latihan yang kontinyu. Dengan latihan secara berkesinambungan ditambah dengan adanya kegemaran seseorang terhadap menulis akan berimplikasi kepada hasil menulisnya

Dengan memperhatikan kelaziman, ketepatan, keserasian, dan keefektifan kata, diharapkan agar isi dan maksud tulisan dapat sampai dengan mudah dan tepat dipahami pembaca. Karena itu, seorang warga belajar tidak akan sembarangan memindahkan buah pikiran dan perasaannya, tanpa mempertimbangkan kata-kata yang akan dipakai.

\section{Tujuan Penelitian}

Secara operasional penelitian ini dilakukan dengan tujuan untuk meningkatkan kemampuan keaksaraan fungsional dalam hal ini hasil belajar membaca dan hasil belajar menulis warga belajar di PKBM Kota Makassar. Secara rinci tujuan penelitian ini adalah untuk mengetahui:
1. Perbedaan hasil belajar membaca dan hasil belajar menulis antara warga belajar yang diberi penilaian portofolio dengan warga belajar yang diberi penilaian konvensional.

2. Perbedaan hasil belajar membaca dan hasil belajar menulis antara warga belajar yang berusia 15 tahun ke bawah dan warga belajar yang berusia di atas 15 tahun.

3. Pengaruh interaksi antara jenis penilaian dan usia terhadap hasil belajar membaca dan hasil belajar menulis

4. Perbedaan hasil belajar membaca dan hasil belajar menulis warga belajar yang berusia 15 tahun ke bawah dan diberi penilaian porofolio dengan warga belajar yang berusia 15 tahun ke bawah dan diberi penilaian konvensional.

5. Perbedaan hasil belajar membaca dan hasil belajar menulis warga belajar yang berusia di atas 15 tahun dan diberi penilaian porofolio dengan warga belajar yang berusia di atas 15 tahun dan dieberi penilaian konvensional.

6. Perbedaan hasil belajar membaca dan hasil belajar menulis warga belajar yang diberi penilaian portofolio dan berusia 15 tahun ke bawah dengan warga belajar yang diberi penilaian portofolio dan berusia di atas 15 tahun.

7. Perbedaan hasil belajar membaca dan hasil belajar menulis warga belajar yang diberi penilaian konvensional dan berusia 15 tahun ke bawah dengan warga belajar yang diberi penilaian konvensional dan berusia di atas 15 tahun.

\section{Perumusan Masalah}

Dari uraian di atas, masalah yang diteliti dirumuskan sebagai berikut:

1. Apakah terdapat perbedaan hasil belajar membaca dan hasil belajar menulis antara warga belajar yang diberi penilaian portofolio dengan warga belajar yang diberi penilaian konvensional?

2. Apakah terdapat perbedaan hasil belajar membaca dan hasil belajar menulis antara warga belajar yang berusia 15 tahun ke bawah dan warga belajar yang berusia di atas 15 tahun?

3. Apakah terdapat pengaruh interaksi antara jenis penilaian dan usia terhadap hasil belajar membaca dan hasil belajar menulis?

4. Apakah terdapat perbedaan hasil belajar membaca dan hasil belajar menulis antara warga belajar yang diberi penilaian portofolio dengan warga belajar yang diberi penilaian konvensional, untuk warga belajar yang berusia 15 tahun ke bawah?

5. Apakah terdapat perbedaan hasil belajar membaca dan hasil belajar menulis antara warga belajar yang 
diberi penilaian portofolio dengan warga belajar yang diberi penilaian konvensional, untuk warga belajar yang berusia di atas 15 tahun?

6. Apakah terdapat perbedaan hasil belajar membaca dan hasil belajar menulis antara warga belajar yang berusia 15 tahun ke bawah dan warga belajar yang berusia di atas 15 tahun, untuk warga belajar yang diberi penilaian portofolio?

7. Apakah terdapat perbedaan hasil belajar membaca dan hasil belajar menulis antara warga belajar yang berusia 15 tahun ke bawah dan warga belajar yang berusia di atas 15 tahun, untuk warga belajar yang diberi penilaian konvensional?

\section{KAJIAN TEORETIS}

\section{Pengertian Hasil Belajar Keaksaraan}

Setiap kegiatan yang dilakukan tentu diharapkan menghasilkan sesuatu, demikian pula halnya dalam belajar. Dalam kegiatan belajar hasil yang diharapkan diperoleh individu yang belajar adalah perubahan tingkah laku. Terjadinya perubahan tingkah laku pada individu akibat belajar tersebut oleh kalangan ahli-ahli psikologi pendidikan diindentifikasi sebagai hasil belajar. Hasil belajar merupakan kemampuan-kemampuan yang dimiliki oleh warga belajar setelah menerima pengalaman dalam proses belajar mengajar, Sejalan dengan pendapat di atas, Briggs mengemukakan bahwa hasil belajar adalah seluruh kecakapan dan hasil yang dicapai oleh warga belajar melalui proses pembelajaran yang dinyatakan dengan angka-angka atau nilai-nilai yang diukur dengan nontes maupun dengan tes hasil belajar

Berkaitan dengan kemampuan yang diperoleh sebagai hasil belajar, Horward Kingsley seperti dikutip oleh Sudjana (1999) membagi tiga bentuk hasil belajar, yakni (1) keterampilan dan kebiasaan, (2) pengetahuan dan pengertian, (3) sikap dan cita-cita. Adapun Gagne membagi hasil belajar dalam lima kategori yaitu: (1) informasi verbal, yaitu kemampuan individu untuk menyatakan kembali informasi yang diperoleh dari proses belajar dalam bentuk bahasa, baik lisan maupun tulisan, (2) keterampilan intelektual yaitu kemampuan yang dimiliki seseorang untuk membedakan, menga-bstraksikan suatu obyek, menghubung-hubungkan konsep dan dapat menghasilkan suatu pengertian, memecahkan suatu persoalan, (3) strategi kognitif, yaitu kemampuan seseorang untuk mengatur dan mengarahkan aktivitas mentalnya sendiri dalam memecahkan masalah yang dihadapinya, (4) sikap adalah kemampuan yang dimiliki seseorang berupa kecenderungan untuk menerima atau menolak suatu obyek berdasarkan penilaian atas obyek tersebut, (5) keterampilan motorik, berupa kemampuan seseorang untuk melakukan serangkaian gerakan jasmani dari anggota badan secara terpadu dan terkoordinasi,

Selanjutnya, Bloom dkk. (1987) membagi di- mensi hasil belajar dalam tiga ranah atau kawasan yakni: (1) ranah kognitif, (2) ranah afektif, dan (3) ranah psikomotor. Ranah kognitif berkenan dengan hasil belajar intelektual yang meliputi enam aspek yakni; (a) pengetahuan atau ingatan, (b) pemahaman, (c) aplikasi, (d) analisis, (e) sintesis, dan (f) evaluasi. Kedua aspek pertama, yakni pengetahuan, pemahaman biasanya digolongkan sebagai tingkat kognitif rendah, sedangkan keempat aspek lainnya, yakni aplikasi, analisis, sintesis, dan evaluasi sering disebut sebagai kognitif tingkat tinggi. Ranah afektif berkenan dengan sikap yang terdiri dari lima aspek yakni; (a) penerimaan, (b) jawaban atau reaksi, (c) penilaian, (d) organisasi, dan (e) internalisasi. Terakhir ranah psikomotor yang berkenan dengan hasil belajar keterampilan dan kemampuan bertindak yang terdiri dari enam aspek, yakni; (a) gerakan refleks, (b) keterampilan gerakan dasar, (c) kemampuan perseptual, (d) keharmonisan atau ketepatan, (e) gerakan keterampilan kompleks, dan (f) gerakan ekspresif dan interpretatif.

Dari berbagai pengklasifikasian hasil belajar yang dikemukakan di atas, dalam sistem pendidikan nasional khususnya dalam merumuskan tujuan pendidikan, baik tujuan kurikuler maupun tujuan instruksional maka klasifikasi hasil belajar yang dikemukakan oleh Bloom yang paling umum digunakan. Artinya ketiga ranah tersebut yang selalu menjadi obyek penilaian hasil belajar. Namun di antara ketiga ranah tersebut maka ranah kognitiflah yang paling banyak dinilai oleh para guru di sekolah dalam kaitannya penguasaan bahan pelajaran, termasuk dalam mata pelajaran keaksaraan.

Berdasarkan uraian-uraian di atas maka dapat dikatakan bahwa yang dimaksud hasil belajar dalam penelitian ini adalah kemampuan yang dicapai oleh warga belajar dalam aspek pengetahuan, pemahaman, aplikasi, analisis, sintesis dan evaluasi setelah warga selesai mengikuti proses pembelajaran keaksaraan (membaca dan menulis) dalam suatu penggalan waktu tertentu. 


\section{Kemampuan Menulis}

Sebagai salah satu keterampilan berbahasa, menulis merupakan keterampilan yang sukar dan kompleks. Dikatakan sukar dan kompleks, banyak warga belajar tidak mampu menulis dengan baik. Ketidakmampuan menulis dengan baik itu disebabkan warga belajar tidak dapat menyusun kalimat dengan baik dan benar, kurangnya kemampuan kosa kata atau ketidakmampuan menentukan kapan mereka harus menulis dan apa yang menjadi ide pokok dalam penulisannya.

Karsana (2002) mengungkapkan bahwa pada hakekatnya menulis adalah pengutaraan sesuatu dengan menggunakan bahasa secara tertulis. Dengan mengutarakan sesuatu itu dimaksudkan menyampai-kan, memberitakan, menceriterakan, melukiskan, menerangkan, meyakinkan, menjelmakan, dan sebagainya kepada pembaca agar mereka memahami apa yang terjadi pada suatu peristiwa atau suatu kegiatan.

Cere mengatakan menulis merupakan komunikasi. Selanjutnya bahwa di dalam komunikasi terdapat empat unsur yaitu: (1) menulis merupakan bentuk ekspresi diri, (2) menulis merupakan sesuatu yang umum disampaikan ke pembaca, (3) menulis merupakan aturan dan tingkah laku, (4) menulis merupakan sebuah cara belajar .

Jadi, yang dimaksud menulis adalah suatu keterampilan berbahasa yang bertujuan untuk memberikan segala bentuk informasi tertulis dari penulis kepada pembaca. Proses pemberian dan penerimaan informasi harus didasarkan pada adanya pemahaman bahasa yang digunakan penulis untuk diserap atau diterima pembaca. Dapat saja terjadi bahwa pembaca bukan penutur bahasa yang digunakan dalam bacaan, tetapi ia memahami bahasa bacaan itu. Dapat pula seorang penulis menuangkan buah pikirannya ke dalam bahasa yang dalam sehari-harinya bukan bahasanya sendiri, dan pembaca pun juga demikian. Semua pemakaian bahasa bertumpu pada pemahaman terhadap bahasa bacaan.

Sehubungan dengan hal di atas, Avelrod dan Copper menyatakan bahwa menulis merupakan suatu proses penemuan yang komplek dan merupakan keterampilan yang membuat seseorang dapat belajar mengatur waktu. Menulis merupakan suatu refleksi dalam diri seseorang yang tumbuh melalui suatu proses. Seseorang dapat menulis dengan baik, tentunya telah melalui berbagai latihan yang kontinyu. Dengan latihan secara berkesinambungan ditambah dengan adanya kegemaran seseorang terhadap menulis akan berimplikasi kepada hasil menulisnya
Dengan memperhatikan kelaziman, ketepatan, keserasian, dan keefekan kata, diharapkan agar isi dan maksud tulisan dapat sampai dengan mudah dan tepat dipahami pembaca. Karena itu, seorang warga belajar tidak akan sembarangan memindahkan buah pikiran dan perasaannya, tanpa mempertimbangkan kata-kata yang akan dipakai.

\section{Kemampuan Membaca}

Membaca menurut Montessori adalah bahasa yang ditulis. Membelajarkan membaca pada orang dewasa berbeda dengan anak-anak, karena mereka sudah punya sikap hidup, pengalaman hidup, pandangan terhadap nilai-nilai hidup, minat, kebutuhan, ide/gagasan, hasrat-hasrat dan dorongan-dorongan untuk melakukan suatu perbuatan. Atas dasar itu membelajarkan membaca pada mereka harus dimulai dari hal-hal di atas, bukan dimulai dari pengenalan dan menghafal huruf-huruf/abjad A - Z. Belajar membaca untuk orang dewasa dimulai dari sesuatu yang bermakna, terdekat, dan melekat dengan dirinya, kemudian meluas dan melebar dari tahapan yang satu ke tahapan berikutnya seperti lingkaran spiral. Sesuatu yang bermakna dan melekat pada warga belajar adalah:"nama diri", meskipun mereka buta aksara tetapi untuk melafalkan nama dirinya dijamin bisa. Bahwa "nama diri" itu terdiri atas lambang-lambang huruf berupa konsonan dan vokal atau rangkaian huruf, bagi mereka mungkin tidak memahami. Alasannya sederhana, kita yang sudah melek aksara pun jika ditanya huruf A, B, dan seterusnya, jika tidak dirangkaikan dalam bentuk kata, huruf-huruf tersebut tidak mempunyai makna/arti.

Mengingat orang dewasa akan lebih cepat dan lebih mudah menerima dan memahami isi bacaan, apabila ia telah menyadari dan menginsafi manfaat dan pentingnya membaca bagi kehidupan, maka dalam pembelajaran membaca bagi warga belajar para tutor senantiasa memperhatikan hal itu. Sebagaimana contoh, ketika seorang warga belajar menyadari dan menginsafi manfaat air bagi kehidupan sehari-hari, maka mereka akan lebih cepat menerima dan memahami apabila mereka dibelajarkan dengan masalah air dan hal-hal yang melingkupinya.

Prinsip-prinsip dan langkah-langlah dalam membelajarkan warga belajar membaca, yaitu: (a) cari materi-materi/informasi praktis atau sederhana yang sesuai dengan minat, kebutuhan, dan masalah yang dihadapi warga belajar (bersifat fungsional), (b) tutor menyalin informasi di atas ke dalam papan tulis, (c) meminta warga belajar untuk menyalin informasi tersebut ke buku catatan masing-masing, (d) tutor membaca bahan bacaan tersebut dan warga belajar menirukan secara bersama-sama dengan melihat 
ke papan tulis, dan (e) meminta warga belajar yang sudah sedikit mampu membaca untuk kedepan dan membaca bahan bacaan tersebut, sementara yang lainnya mengikuti, (f) latih mereka berulang-ulang, (g) meminta warga belajar membaca secara bersamaan dengan melihat hasil tulisannya masing-masing (bukan ke papan tulis), (h) latih mereka membaca hasil tulisan masing-masing secara bergantian/acak, (i) jangan terlalu khawatir bila warga belajar tidak dapat membaca dengan sempurna, dan (j) bantulah warga belajar agar percaya diri dan merasa senang bahwa mereka dapat membaca, dan beri semangat pada warga belajar untuk membantu yang lainnya.

Oleh karena warga belajar kelompok belajar keaksaraan fungsional biasanya terdiri atas multi-level, maka tutor harus membuat rencana tentang cara melibatkan warga belajar dari semua level/tingkat kemampuan untuk belajar membaca. Atas dasar itu, maka di dalam mengelola kegiatan belajar di kelompok belajar, tutor dapat menggunakan pendekatan "klasikal" (warga belajar hanya meniru bacaan dari tutor pada papan tulis), agar mereka tidak merasa rendah diri akan kemampuan membacanya. Berbeda untuk kelompok belajar yang warga belajarnya memiliki kemampuan beragam: (a) pilih salah satu teks bacaan yang sesuai dengan minat, kebutuhan dan permasalahan yang dihadapi warga belajar, (b) salin teks bacaan tersebut ke papan tulis, (c) tutor membacakan dan warga belajar menirukan (baik bersama-sama, kelompok kecil, maupun individu) secara bergiliran, (d) meminta warga belajar menyalin teks bacaan tersebut ke dalam buku masing-masing, dan (e) ulangi proses di atas sekali lagi, sebelum meminta warga belajar membaca hasil tulisannya masing-masing atau saling menukarkan hasil tulisan temannya.

\section{Pengertian Penilaian}

Istilah penilaian menurut Witherington dkk. pada hakikatnya sama dengan istilah evaluasi. Oleh karena itu istilah penilaian yang dipakai dalam penelitian ini diartikan sebagai padanan kata evaluasi. Menurut Nurkencana dan Sumartana istilah evaluasi berasal dari bahasa Inggris yaitu 'evaluation' yang berarti suatu tindakan atau suatu proses untuk menentukan nilai segala sesuatu. Secara ringkas, Cronbach mengemu-kakan bahwa penilaian adalah suatu kegiatan menyediakan informasi untuk mengambil keputusan. Selanjutnya Mahrens dan Lehman seperti dikutip oleh Djiwandono mengatakan, evaluasi adalah suatu proses untuk merencanakan, memperoleh dan menyediakan informasi yang sangat diperlukan untuk membuat alternatif-alternatif keputusan. Dengan demikian dapat dikatakan bahwa penilaian dalam arti luas adalah suatu proses kegiatan yang diarahkan untuk mendapatkan informasi tentang sesuatu dalam rangka pengambilan keputusan.

Dalam kaitannya dengan kegiatan belajar me-ngajar, Gronlund merumuskan pengertian penilaian sebagai suatu proses yang sistematis untuk mengum-pulkan, menganalisis, dan menginterpretasi informasi dalam rangka menentukan tingkat keberhasilan warga belajar terhadap tujuan instruksional. Adapun Zainul dan Nasoetion (1997) mengartikan penilaian sebagai suatu proses untuk mengambil keputusan dengan menggunakan informasi yang diperoleh melalui pengukuran hasil belajar, baik yang menggunakan instrumen tes maupun non tes. Selanjutnya, Basir merumuskan pengertian penilaian sebagai suatu kegiatan yang ditujukan untuk mengukur sampai seberapa jauh tujuan instruksional suatu program pengajaran telah tercapai.

Dari berbagai pengertian penilaian yang dikemukakan di atas, maka dapat ditarik suatu kesimpulan bahwa penilaian pada hakikatnya adalah suatu proses untuk menentukan sejauh mana warga belajar menguasai tujuan-tujuan pembelajaran yang telah ditetapkan sebelumnya.

\section{Pengertian Penilaian Portofolio}

Penilaian portofolio merupakan salah satu bentuk penilaian hasil belajar terhadap sekumpulan karya warga belajar yang tersusun secara sistematis dan terorganisasi yang diambil selama proses pembelajaran dalam kurun waktu tertentu, digunakan oleh tutor dan warga belajar untuk memantau perkembangan pengetahuan, keterampilan dan sikap warga belajar dalam mata pelajaran tertentu seperti pelajaran menulis dan membaca.

Menurut Barton \& Collins (1997) membedakan empat macam objek portofolio yaitu: (1) hasil karya peserta didik (artifacts), yaitu hasil kerja peserta didik yang dihasilkan di kelas, (2) reproduksi (reproduction) yaitu hasil kerja peserta didik yang dikerjakan di luar kelas, (3) pengesahan (attestations) yaitu pernyataan dan hasil pengamatan yang dilakukan oleh guru atau pihak lainnya tentang peserta didik, dan (4) produksi (production) yaitu hasil kerja peserta didik yang dipersiapkan khusus untuk portofolio.

Pengertian portofolio diungkapkan oleh Surapratana dan Hatta (2004) sebagai berikut: portofolio diartikan sebagai kumpulan hasil evidence atau hasil belajar atau karya peserta didik yang menunjukkan usaha, perkembangan, prestasi belajar peserta didik dari waktu ke waktu dan dari satu mata pelajaran ke pelajaran yang lain. Portofolio secara sederhana dapat juga diartikan sebagai bukti-bukti pengalaman belajar 
peserta didik yang dikumpulkan sepanjang waktu, misalnya selama satu semester atau satu tahun.

Penilaian portofolio merupakan pendekatan baru yang akhir-akhir ini sering diperkenalkan para ahli pendidikan untuk dilaksanakan di sekolah-sekolah selain pendekatan penilaian yang telah lama digunakan. Demikian juga untuk pendidikan luar sekolah, penilaian portofolio juga sebagai pendekatan penilaian yang efektif untuk menilai kemajuan dan keberhasilan belajar bagi warga belajar. Melalui penilaian portofolio warga belajar dapat ditunjukkan perbedaan kemampuan dalam menyelesaikan tugas yang diberikan oleh tutor dari waktu ke waktu dibandingkan dengan evidence warga belajar lain.

\section{Fungsi dan Tujuan Penilaian Portofolio}

Portofolio digunakan sebagai alat pengajaran dan juga sebagai alat penilaian. Penilaian portofolio mengharuskan warga belajar untuk mengoleksi dan menunjukkan hasil kerja mereka. Dalam hal ini penilaian potofolio dapat dianggap sebagai salah satu alat pengajaran yang merupakan komponen kurikulum. Dalam penilaian portofolio warga belajar memiliki kesempatan yang lebih banyak untuk menilai diri sendiri dari waktu ke waktu.

Penilaian portofolio bertujuan sebagai alat formatif maupun sumatif. Portofolio sebagai alat formatif digunakan untuk memantau kemajuan warga belajar dari hari ke hari dan untuk mendorong warga belajar dalam merefleksikan pembelajaran mereka sendiri. Portofolio seperti ini difokuskan pada proses perkembangan warga belajar dan digunakan untuk tujuan formatif dan diagnositik.

Portofolio dijadikan sebagai suatu bentuk penilaian, memiliki landasan pemikiran dan prinsip dasar yang dapat dilihat sebagai berikut:

1. Landasan pemikiran penilaian portofolio

a. Membelajarkan kembali (re-edukasi)

Menurut cara berfikir baru, menilai itu bukan menvonis warga belajar dengan harga mati, lulus atau gagal. Menilai adalah mencari informasi tentang pengalaman belajar warga belajar dan informasi tersebut dipergunakan sebagai balikan (feed back) untuk membelajarkan kembali.

\section{b. Merefleksikan pengalaman belajar}

Suatu gagasan yang baik apabila penilaian dijadikan media untuk merefleksi (bercermin) pada pengalaman yang telah dimiliki oleh warga belajar dan kegiatan yang mereka selesaikan. Refleksi pengalaman belajar merupakan suatu cara untuk belajar, menghindari kesalahan di masa yang akan datang dan untuk meningkatkan kinerja.

2. Prinsip-prinsip penilaian portofolio
Berbeda dengan penilaian bentuk lainnya, keterlibatan warga belajar dalam penilaian portofolio merupakan sesuatu yang harus dikerjakan. Ada beberapa prinsip yang perlu diperhatikan dan dijadikan pedoman dalam penggunaan penilaian portofolio, antara lain saling percaya, kerahasiaan bersama, milik bersama, kepuasan, kesesuaian, proses, dan hasil (Sumarna, 2004: 77).

\section{Penilaian Konvensional}

Kegiatan belajar mengajar adalah suatu proses yang dilakukan secara sengaja dengan tujuan-tujuan tertentu. Untuk mengetahui apakah kegiatan tersebut berhasil mencapai tujuan atau tidak maka diperlukan adanya suatu penilaian. Berkenan dengan penilaian secara umum, Scriven seperti dikutip Tayibnapis (2000) membedakan dua macam penilaian yakni, penilaian formatif dan penilaian sumatif. Fungsi formatif penilaian dipakai untuk perbaikan atau pengembangan kegiatan yang sedang berjalan, sedangkan fungsi sumatif penilaian dipakai untuk pertanggungjawaban, sertifikasi, seleksi, atau kelanjutan.

Dalam konteks proses belajar mengajar, Tessmer (1995) menyatakan bahwa penilaian formatif adalah suatu tahapan kegiatan yang dilakukan pada saat suatu bagian materi pelajaran telah selesai diberikan kepada warga belajar. Penilaian ini dilakukan untuk mengetahui sejauh mana para warga belajar telah memahami materi pelajaran tersebut dan juga untuk mengetahui kelemahan-kelemahan yang terjadi pada proses pembelajaran, seperti ketepatan penggunaan metode, media, dan sistim penilaian yang digunakan. Jadi pada dasarnya penilaian formatif dilakukan dalam rangka memperoleh umpan balik yang tepat sehingga proses pembelajaran yang sedang dilaksanakan dapat disempurnakan ke arah yang lebih baik. Berhubung karena dipakai sebagai umpan balik maka penilaian formatif menurut Ali sebaiknya dilaksanakan setiap kali selesai dipelajari suatu unit pelajaran tertentu.

Selanjutnya, Guba dan Lincoln (1988) memberikan penekanan bahwa tujuan penilaian formatif adalah untuk perbaikan dan penyempurnaan apa yang telah dilakukan. Pengertian lain yang hampir sama dikemukakan oleh Sukardi dan Maramis bahwa penilaian formatif bertujuan memberi umpan balik kepada warga belajar tentang hasil belajarnya, apakah sudah baik ataukah masih ada hal-hal yang harus dilaksanakan untuk mencapai tujuan pembelajaran yang telah ditetapkan sebelumnya. Dalam penilaian pembelajaran suatu penilaian disebut formatif jika tujuan utamanya adalah untuk mengumpulkan informasi yang bermanfaat dalam rangka menentukan tentang bagaimana cara mengajar. 
Dari berbagai pendapat dan uraian di atas, ternyata terungkap begitu penting dan perlunya penilaian formatif diberikan sesering mungkin, kalau perlu setiap pertemuan, dalam rangka penyempurnaan proses belajar mengajar pada umumnya, dan pembelajaran sejarah pada khususnya agar supaya hasil belajar sejarah warga belajar dan mutu pendidikan pada umumnya dapat lebih berkualitas. Namun demikian perlu diperhatikan bahwa latihan atau penilaian yang diberikan sesering mungkin menurut Suparno hendaknya dijaga jangan sampai menimbulkan overlearning, yaitu pemberian latihan yang terlalu banyak yang membuat warga belajar menjadi bosan dan jenuh yang kemudian berakibat pada kemunduran hasil belajarnya.

\section{Usia dan Perspektif Belajar}

Usia merupakan salah satu variabel yang ikut menentukan keberhasilan seseorang dalam belajar, dan perbedaan tingkatan usia akan mempengaruhi tingkat intelektual seseorang. Variabel usia dalam penelitian ini di bagi dalam dua kategori, yaitu; 1) usia 15 tahun ke bawah; dan 2) usia di atas 15 tahun. Pembagian usia ini didasarkan atas usia wajib belajar sekolah dasar 9 tahun, yaitu 7-15 tahun, dan usia ini masih dikategorikan anak-anak. Sedangkan usia di atas 15 tahun dikategorikan orang dewasa, walaupun usia 16-20 ada sebahagian pendapat yang mengkategorikan sebagai usia dewasa awal, karena usia ini merupakan peralihan dari usia kanak-kanak ke usia masa dewasa. Dalam usia ini individu mulai memainkan peran sebagai orang dewasa dalam berbagai bidang kehidupan dalam masyarakat.

Usia kanak-kanak merupakan usia peka. Dalam tahapan ini, perkembangan fungsi penalaran intelektual pada anak sangat dominan, dan dalam pertumbuhan pula ini sistem syaraf serta fungsi pikirannya, anak mulai kritis dalam menanggapi sesuatu ide atau pengetahuan dari orang lain. Dengan pikirannya yang berkembang, anak mulai belajar menemukan tujuan-tujuan serta keinginan-keinginan yang dianggap sesuai baginya untuk memperoleh kebahagian.

\section{Hasil Penelitian yang Relevan}

Dalam suatu penelitian, anak usia tujuh sampai tigabelas tahun yang sebagian berkemampuan membaca normal dan sebagian buruk, diberi serangkaian kalimat yang tidak lengkap dan diminta untuk dilengkapinya: "Di musin panas hawanya sangat . . . . .", "Waktu makan malam, kita biasanya makan roti dan . .

... "Setelah melengkapi kalimat, anak-anak itu diminta untuk mengulangi kata terakhir yang mereka tulis untuk setiap kalimat. Hasil penelitian tersebut menunjukkan bahwa semakin tua usia anak, kapasitas working memory-nya meningkat baik itu untuk anak normal maupun yang bermasalah, tetapi pembaca yang bermasalah ini punya kapasitas working memory yang lebih rendah (rentang memori yang lebih pendek) ketimbang pembaca normal di setiap level usia. Jadi menurut penelitian tersebut jika dihubungkan dengan tingkatan usia dapat disimpulkan bahwa anak usia di atas 15 tahun lebih tinggi kapasitas memori dalam membaca dibanding anak usia 15 tahun ke bawah.

Hasil penelitian yang dilakukan para peneliti, telah menemukan bahwa semakin dewasa seseorang, semakin mungkin ia merevisi tulisan mereka ketimbang anak usia muda yang belum berpengalaman. Penelitian tersebut menunjukkan bahwa semakin sering sesorang menulis maka semakin baik dalam kemampuan menulisnya, karena dalam keseringan tersebut sesorang dapat melihat kembali atau merevisi tulisannya dan akhirnya dapat menyempurnakan hasil tulisan tersebut. Dalam hal ini pula hasil penelitian tersebut berhubngan dengan penilaian portofolio tentang penilaian hasil karaya sesorang, yang jauh lebih baik bagi orang dewasa dari pada anak-anak.

\section{Kerangka Berpikir}

1. Perbedaan hasil belajar membaca dan hasil belajar menulis antara warga belajar yang diberi penilaian portofolio dengan warga belajar yang diberi penilaian konvensional.

Penilaian portofolio merupakan proses penilaian yang berlangsung dua arah antara tutor dan warga belajar lainnya. Dalam penilaian portofolio antara tutor dan warga belajar memiliki rasa saling mempercayai saling memerlukan dan memiliki semangat untuk saling membantu. Oleh karena itu, antara tutor dan warga belajar saling terbuka dan jujur satu sama lain. Tutor menciptakan suasana pembelajaran dan penilaian yang dapat dengan mudah memperlihatkan kemampuannya secara optimal sesuai dengan harapan standar kompetensi, kompetensi dasar, dan indikator yang dituntut dalam kurikulum. Penilaian portofolio memberikan kesempatan untuk melakukan refleksi bersama-sama, dimana warga belajar dapat merefleksikan tentang proses berpikir mereka sendiri, tentang kemampuan pemahaman mereka sendiri, pemecahan masalah atau pengambilan keputusan, dan mengamati pemahaman mereka tentang kompetensi dasar dan indikator yang telah mereka peroleh.

Penilaian konvensional setiap kompetensi dasar adalah salah satu jenis penilaian warga belajar di satuan pendidikan luar sekolah yang dilaksanakan secara berkelanjutan pada akhir setiap pembahasan kompetensi dasar tertentu, dimaksudkan untuk mengetahui sejauh mana warga belajar telah menguasai kompetensi dasar yang telah ditentukan sebelumnya. 
Akhir setiap kompetensi dasar adalah merupakan pernyataan minimal atau memadai tentang pengetahuan, keterampilan, sikap, dan nilai-nilai yang direfleksikan dalam kebiasaan berpikir dan bertindak setelah warga belajar menyelesaikan suatu aspek atau sub aspek mata pelajaran tertentu. Penilaian konvensional setiap kompetensi dasar sama dengan ulangan harian yaitu suatu ulangan yang dilakukan setiap selesai proses pembelajaran dalam satuan bahasan atau kompetensi dasar tertentu dan biasanya dilakukan minimal tiga kali dalam setiap semester.

Berdasarkan uraian di atas maka dapat dikemukakan bahwa penilaian portofolio merupakan suatu bentuk penilaian yang sesuai dengan karakteristik warga belajar, karena portofolio dapat diartikan sebagai suatu bundel atau wujud benda fisik hasil kerja warga belajar. Sebaliknya penilaian konvensional lebih mendasarkan pada tes setiap akhir pokok bahasan atau satuan waktu tertentu selama proses pembelajaran. Dengan demikian diduga bahwa hasil belajar membaca dan hasil belajar menulis pada warga belajar yang diberi penilaian portofolio lebih tinggi daripada warga belajar yang diberi penilaian konvensional.

2. Perbedaan hasil belajar membaca dan hasil belajar menulis antara warga belajar yang berusia 15 tahun ke bawah dan warga belajar yang berusia di atas 15 tahun.

Usia 15 tahun ke bawah merupakan usia peka. Dalam usia ini, perkembangan fungsi penalaran intelektual pada anak sangat dominan, dan dalam pertumbuhan ini pula sistem syaraf serta fungsi pikirannya, anak mulai kritis dalam menanggapi sesuatu ide atau pengetahuan dari orang lain. Dengan pikirannya yang berkembang, anak mulai belajar menemukan tujuan-tujuan serta keinginan-keinginan yang dianggap sesuai baginya untuk memperoleh kepuasan dari hasil belajarnya.

Sementara itu usia di atas 15 tahun merupakan usia dewasa atau suatu bahagian dari proses yang berkelanjutan dari masa usia 15 tahun. Keadaan yang dialami orang dewasa sekarang ini merupakan masa bagi seseorang untuk memantapkan kemampuan dan keterampilan dasar yang telah diperolehnya di masa usia kanak-kanak. Pada usia dewasa kemampuan dan keterampilan dasar yang telah diperoleh, selain dimantapkan, juga dikembangkan sehingga makin banyak pengetahuan dan keterampilan baru yang diperoleh, yang pada gilirannya akan makin lebih mantap dalam belajar lebih lanjut.

Mengacu pada perkembangan dari tingkat usia, kemudian dikaitkan dengan kemampuan membaca dan menulis seseorang, maka dapat diduga antara warga belajar yang berusia 15 tahun ke bawah dan warga belajar yang berusia di atas 15 tahun terdapat perbedaan dalam pencapaian hasil belajar membaca dan hasil belajar menulis. Warga belajar yang berusia di atas 15 tahun kemampuan dan keterampilan dasar yang telah diperoleh, selain dimantapkan, juga dikembangkan sehingga makin banyak pengetahuan dan keterampilan baru yang diperoleh, yang pada gilirannya akan makin lebih mantap dalam belajar lebih lanjut. Sebaliknya warga belajar yang usia 15 tahun ke bawah baru memulai belajar menemukan tujuan-tujuan serta keinginan-keinginan yang dianggap sesuai baginya. Dengan demikian dapat diduga bahwa warga belajar yang usia di atas 15 tahun akan mencapai hasil belajar membaca dan menulis yang lebih tinggi dari pada warga belajar yang usia 15 tahun ke bawah.

3. Pengaruh Interaksi Antara Jenis Penilaian dengan Usia terhadap Hasil Belajar Membaca dan Hasil Belajar Menulis

Hasil belajar merupakan ukuran keberhasilan warga belajar dalam memahami materi yang diberikan. Ukuran keberhasilan tersebut dapat diketahui berdasarkan skor hasil penilaian yang dilakukan sebelumnya. Seorang warga belajar dikatakan berhasil jika ia mampu mencapai skor maksimal yang telah ditentukan. Untuk mencapai skor yang telah ditentukan tersebut maka warga belajar harus belajar maksimal dengan mengarahkan segala potensi yang dimiliki. Salah satu cara mendorong warga belajar untuk selalu belajar maksimal adalah dengan memberikan penilaian sesuai dengan karakteristik yang dimiliki oleh warga belajar.

Warga belajar merupakan individu yang unik artinya tidak ada dua orang warga belajar yang sama persis, tiap warga belajar memiliki perbedaan satu dengan yang lain. Perbedaan itu dapat berupa tingkatan usia, cara berpikir, kepribadian, gaya belajar, dan sebagainya. Perbedaan individual tersebut berpengaruh pada cara dan hasil belajar warga belajar. Karenanya perbedaan individual perlu mendapat perhatian dari tutor dalam upaya meningkatkan pencapaian hasil belajar. Oleh karena itu, tutor harus mengintegrasikan berbagai jenis penilaian dalam proses belajar mengajar seperti jenis penilaian portofolio dan penilaian konvensional pada warga belajar yang memiliki usia baik 15 tahun ke bawah maupun di atas 15 tahun. Dengan demikian dapat diduga bahwa pengaruh jenis penilaian terhadap hasil belajar membaca dan menulis bergantung pada tingkat usia warga belajar.

4. Perbedaan hasil belajar membaca dan hasil belajar menulis antara warga belajar yang diberi penilaian portofolio dan warga belajar yang diberi penilaian 
konvensional, untuk warga belajar yang berusia 15 tahun ke bawah.

Bagi warga belajar yang memiliki usia 15 tahun ke bawah sudah berada pada tahap operasi formal. Pada kelompok umur tersebut, warga belajar memperlihatkan adanya suatu masa transisi utama dalam proses berpikir. Kelompok umur tersebut warga belajar telah mampu berpikir abstrak, menggunakan berbagai teori, dan menggunakan berbagai hubungan logis tanpa harus menunjuk pada hal-hal yang konkret. Tahapan opersi formal ini merupakan landasan yang memungkinkan anak melakukan pemecahan berbagai masalah. Meskipun kelompok umur tersebut sudah bisa dikategorikan pada tahap operasi formal, namun masih banyak anak yang berada pada tahapan opersi kongkret. Mereka masih memerlukan banyak bantuan dan latihan agar memiliki landasan yang kuat untuk mencapai tahapan opersi formal. Transisi dari suatu tahapan ke tahapan yang lain memerlukan kematangan.

Penilaian portofolio merupakan salah satu bentuk penilaian hasil belajar terhadap sekumpulan karya warga belajar yang tersusun secara sistematis dan terorganisasi yang diambil selama proses pembelajaran dalam kurun waktu tertentu, digunakan oleh tutor dan warga belajar untuk memantau perkembangan pengetahuan, keterampilan dan sikap warga belajar dalam mata pelajaran tertentu seperti pelajaran menulis dan membaca. Berbeda dengan penilaian bentuk konvensional, keterlibatan warga belajar dalam penilaian portofolio merupakan sesuatu yang harus dikerjakan.

Pada penilaian portofolio ada beberapa prinsip yang perlu diperhatikan dan dijadikan pedoman dalam penggunaan penilaian portofolio, antara lain saling percaya, kerahasiaan bersama, milik bersama, kepuasan, kesesuaian, proses, dan hasil. Sementara pada penilaian konvensional suatu tahapan kegiatan yang dilakukan pada saat suatu bagian materi pelajaran telah selesai diberikan kepada warga belajar.

Mengacu pada karakteristik warga belajar yang memiliki usia 15 tahun ke bawah kemudian dikaitkan dengan karakteristik penilaian portofolio dan penilaian konvensional sebagaimana yang diuraikan di atas, dapat diduga bahwa untuk warga belajar yang memiliki usia 15 tahun ke bawah, hasil belajar membaca dan menulis warga belajar yang diberi penilaian portofolio lebih tinggi daripada warga belajar yang diberi penilaian konvensional.

5. Perbedaan hasil belajar membaca dan hasil belajar menulis antara warga belajar yang diberi penilaian portofolio dan warga belajar yang diberi penilaian konvensional, untuk warga belajar yang berusia di atas 15 tahun.
Bagi warga belajar yang memiliki usia di atas 15 tahun dapat dikelompokan pada kelompok orang dewasa. Kelompok umur tersebut akan termotivasi untuk belajar karena kebutuhan dan minat dimana belajar akan memberikan kepuasan, orientasi pembelajaran kelompok umur tersebut adalah berpusat kepada kehidupan nyata, pengalaman sebagai sumber terbaik bagi kelompok umur tersebut. Perbedaan diantara warga belajar usia di atas 15 tahun semakin meningkat dengan bertambahnya usia, oleh karena itu memberi pilihan dalam hal perbedaan gaya belajar dan jenis penilaian yang digunakan.

Penilaian portofolio menerapkan prinsip proses dan hasil. Proses belajar yang dinilai misalnya diperoleh dari catatan perilaku harian warga belajar (anecdot) mengenai sikapnya dalam belajar, antusias tidaknya dalam mengikuti pelajaran dan sebagainya. Aspek lain dari penilaian portofolio adalah penilaian hasil, yaitu menilai hasil akhir suatu tugas yang diberikan oleh tutor. Dengan demikian maka penilaian portofolio tidak sekedar menilai hasil akhir pembelajaran, melainkan juga perlu memberikan penilaian terhadap proses belajar.

Hasil akhir portofolio adalah ketercapaian standar kompetensi, kompetensi dasar, dan indikator. Kepuasan semua pihak terletak pada tercapai tidaknya standar kompetensi, kompetensi dasar, maupun indikator tersebut yang dimanifestasikan melalui dokumen warga belajar. Seluruh dokumen warga belajar dari awal mereka belajar sampai pada akhir kurun waktu tertentu disimpan di tempat yang aman dan mudah diakses. Sementara penilaian konvensional setiap kompetensi dasar yang pelaksanaannya lebih jarang, sehingga tidak menuntut kesiapan, perhatian, dan motivasi yang tinggi dari warga belajar dalam kegiatan pembelajaran.

Mengacu pada karakteristik siswa yang memilki usia di atas 15 tahun kemudian dikaitkan dengan karakteristik penilaian portofolio dan penilaian konvensional sebagaimana diuraikan di atas, dapat diduga bahwa untuk warga belajar yang memiliki usia di atas 15 tahun, hasil belajar membaca dan hasil belajar menulis warga belajar yang diberi penilian portofolio lebih tinggi daripada warga belajar yang diberi penilaian konvensional.

6. Perbedaan hasil belajar membaca dan hasil belajar menulis antara warga belajar yang berusia 15 tahun ke bawah dan warga belajar yang berusia di atas 15 tahun, untuk warga belajar yang diberi penilaian portofolio.

Dalam konteks penilaian portofolio dapat diartikan sebagai kumpulan karya atau dokumen warga be- 
lajar yang tersusun secara sistematis dan terorganisasi yang diambil selama proses pembelajaran, digunakan oleh tutor dan warga belajar untuk menilai dan memantau perkembangan pengetahuan, keterampilan, dan sikap warga belajar dalam mata pelajaran tertentu. Portofolio dapat memberikan bahan tindak lanjut dari suatu pekerjaan yang telah dilakukan warga belajar sehingga tutor dan warga belajar berkesempatan untuk mengembangkan kemampuannya. Portofolio berfungsi untuk melihat perkembangan tanggung jawab warga belajar dalam belajar, perluasan dimensi belajar, pembaharuan kembali proses belajar-mengajar, dan penekanan pada pengembangan pandangan warga belajar dalam belajar. Penilaian portofolio memberikan kesempatan untuk melakukan refleksi bersama-sama, dimana warga belajar dapat merefleksikan tentang proses berpikir mereka sendiri, tentang kemampuan pemahaman mereka sendiri, pemecahan masalah atau pengambilan keputusan, dan mengamati pemahaman mereka tentang kompetensi dasar dan indikator yang telah mereka peroleh.

Bagi warga belajar yang memiliki usia di atas 15 tahun dapat dikelompok pada kelompok orang dewasa. Kelompok umur tersebut akan termotivasi untuk belajar karena kebutuhan dan minat dimana belajar akan memberikan kepuasan, orientasi pembelajaran kelompok umur tersebut adalah berpusat kepada kehidupan nyata, pengalaman sebagai sumber terbaik bagi kelompok umur tersebut. Perbedaan diantara warga belajar usia di atas 15 tahun semakin meningkat dengan bertambahnya usia, oleh karena itu memberi pilihan dalam hal perbedaan gaya belajar dan jenis penilaian yang digunakan.

Sementara, warga belajar yang memiliki usia 15 tahun ke bawah sudah berada pada tahap operasi formal. Pada kelompok umur tersebut, warga belajar memperlihatkan adanya suatu masa transisi utama dalam proses berpikir. Meskipun kelompok umur tersebut sudah bisa dikategorikan pada tahap operasi formal, namun masih banyak anak yang berada pada tahapan opersi kongkret. Mereka masih memerlukan banyak bantuan dan latihan agar memiliki landasan yang kuat untuk mencapai tahapan opersi formal. Transisi dari suatu tahapan ke tahapan yang lain memerlukan kematangan.

Mengacu pada karakteristik model penilaian portofolio dengan karakteristik warga belajar yang berusia di atas 15 tahun dan yang berusia 15 tahun ke bawah sebagaimana diuraikan di atas, dapat dikemukakan bahwa model penilaian portofolio lebih cocok diberikan kepada warga belajar yang memiliki usia di atas 15 tahun daripada warga belajar yang berusia 15 tahun ke bawah. Dengan demikian dapat diduga bahwa untuk warga belajar yang diberi model penilaian portofolio, hasil belajar membaca dan menulis warga belajar yang usia di atas 15 tahun lebih tinggi daripada warga belajar yang usia 15 tahun ke bawah.

7. Perbedaan hasil belajar membaca dan hasil belajar menulis antara warga belajar yang berusia 15 tahun ke bawah dan warga belajar yang berusia di atas 15 tahun, untuk warga belajar yang diberi penilaian konvensional

Model penilaian konvensional adalah penilaian yang dimaksudkan untuk memantau kemajuan belajar warga belajar selama proses belajar mengajar berlangsung dalam suatu program pembelajaran tertentu pada setiap selesai satu pertemuan atau setiap selesai satu kompetensi dasar tertentu. Penilaian konvensional tersebut dilakukan dengan cara tes lisan, tertulis, dan perbuatan. Tes lisan dilakukan pada awal kegiatan pembelajaran, yaitu untuk mengetahui pengetahuan awal warga belajar dan pada akhir tata muka untuk mengetahui daya serap warga belajar. Adapun tes tertulis digunakan untuk mengetahui hasil belajar yang dapat dilakukan pada kompetensi dasar tertentu, tengah semester, akhir semester, atau akhir setiap kegiatan pembelajaran. Selanjutnya untuk tes perbuatan digunakan untuk mengukur penguasaan hal-hal yang berkaitan dengan keterampilan seperti menyajikan hasil tugas, mengikuti diskusi, dan lain-lain.

Bagi warga belajar yang memiliki usia 15 tahun ke bawah sudah berada pada tahap operasi formal. Kelompok umur tersebut warga belajar telah mampu berpikir abstrak, menggunakan berbagai teori, dan menggunakan berbagai hubungan logis tanpa harus menunjuk pada hal-hal yang konkret. Tahapan opersi formal ini merupakan landasan yang memungkinkan anak melakukan pemecahan berbagai masalah.

Sementara, warga belajar yang memiliki usia di atas 15 tahun kesiapan belajarnya tergatung pada kuantitas pembelajaran yang sudah ada sebelumnya, bahan belajar akan dipelajari apabila sesuai dengan kebiasaannya, motivasi belajarnya lemah, hanya untuk belajar sesuai dengan kebutuhan yang diirasakannya serta minatnya, dimana proses belajar diasumsikan dapat memenuhi kebutuhannya saja, dan lingkungan mempengaruhi pembelajarannya.

Mengacu pada karakteristik model penilaian konvensional dengan karakteristik warga belajar yang berusia 15 tahun ke bawah dan yang berusia di atas 15 tahun sebagaimana diuraikan di atas, dapat dikemukakan bahwa model penilaian konvensional lebih cocok diberikan kepada warga belajar yang memiliki usia 15 tahun ke bawah daripada warga belajar yang berusia 
di atas 15 tahun. Dengan demikian dapat diduga bahwa untuk warga belajar yang diberi model penilaian konvensional, hasil belajar membaca dan menulis warga belajar yang usia 15 tahun ke bawah lebih tinggi daripada warga belajar yang usia di atas 15 tahun.

\section{Hipotesis Penelitian}

Berdasarkan beberapa teori dan kerangka berpikir yang telah dikemukakan, maka hipotesis penelitian ini dapat dirumuskan sebagai berikut:

1. Hasil belajar membaca dan hasil belajar menulis warga belajar yang diberi penilaian portofolio lebih tinggi daripada warga belajar yang diberi penilaian konvensional.

2. Hasil belajar membaca dan hasil belajar menulis warga belajar yang berusia di atas 15 tahun lebih tinggi daripada warga belajar yang berusia 15 tahun ke bawah.

3. Terdapat pengaruh interaksi antara jenis penilaian dengan tingkatan usia terhadap hasil belajar membaca dan hasil belajar menulis
4. Untuk warga belajar yang berusia 15 tahun ke bawah, hasil belajar membaca dan hasil belajar menulis warga belajar yang diberi penilaian portofolio lebih tinggi daripada warga belajar yang diberi penilaian konvensional.

5. Untuk warga belajar yang berusia di atas 15 tahun, hasil belajar membaca dan hasil belajar menulis warga belajar yang diberi penilaian portofolio lebih tinggi daripada warga belajar yang diberi penilaian konvensional.

6. Untuk warga belajar yang diberi penilaian portofolio, hasil belajar membaca dan hasil belajar menulis warga belajar yang berusia di atas 15 tahun lebih tinggi daripada warga belajar yang berusia 15 tahun ke bawah.

7. Untuk warga belajar yang diberi penilaian konvensional, hasil belajar membaca dan hasil belajar menulis warga belajar yang berusia 15 tahun ke bawah lebih tinggi daripada warga belajar yang berusia di atas 15 tahun.

\section{METODOLOGI PENELITIAN}

\section{Tujuan Penelitian}

Secara operasional penelitian ini dilakukan dengan tujuan untuk meningkatkan kemampuan keaksaraan fungsional dalam hal ini hasil belajar membaca dan hasil belajar menulis warga belajar di PKBM Kota Makassar. Secara rinci tujuan penelitian ini adalah untuk mengetahui:

1. Perbedaan hasil belajar membaca dan hasil belajar menulis antara warga belajar yang diberi penilaian portofolio dengan warga belajar yang diberi penilaian konvensional.

2. Perbedaan hasil belajar membaca dan hasil belajar menulis antara warga belajar yang berusia 15 tahun ke bawah dan warga belajar yang berusia di atas 15 tahun.

3. Pengaruh interaksi antara jenis penilaian dan usia terhadap hasil belajar membaca dan hasil belajar menulis

4. Perbedaan hasil belajar membaca dan hasil belajar menulis warga belajar yang berusia 15 tahun ke bawah dan diberi penilaian porofolio dengan warga belajar yang berusia 15 tahun ke bawah dan diberi penilaian konvensional.

5. Perbedaan hasil belajar membaca dan hasil belajar menulis warga belajar yang berusia di atas 15 tahun dan diberi penilaian porofolio dengan warga belajar yang berusia di atas 15 tahun dan diberi penilaian konvensional.
6. Perbedaan hasil belajar membaca dan hasil belajar menulis warga belajar yang diberi penilaian portofolio dan berusia 15 tahun ke bawah dengan warga belajar yang diberi penilaian portofolio dan berusia di atas 15 tahun.

7. Perbedaan hasil belajar membaca dan hasil belajar menulis warga belajar yang diberi penilaian konvensional dan berusia 15 tahun ke bawah dengan warga belajar yang diberi penilaian konvensional dan berusia di atas 15 tahun.

\section{Tempat dan Waktu Penelitian}

Penelitian ini dilaksanakan di Kota Makassar. Penentuan tempat tersebut dengan pertimbangan bahwa Kota Makassar memiliki populasi warga belajar yang cukup besar dibandingkan dengan populasi warga belajar pada PKBM di kota-kota lain di wilayah Sulawesi Selatan.

Waktu pelaksanaan mulai minggu pertama April 2005 yang diawali konsultasi dengan pihak PLS Kota Makassar, validasi instrumen, dan perlakuan pelaksanaan eksperimen serta pengambilan data hasil belajar membaca dan hasil belajar menulis. Proses penelitian berlangsung pada satu periode pelaksanaan program (6 bulan).

\section{Populasi dan Teknik Pengambilan Sampel}

Populasi penelitian ini adalah seluruh warga belajar yang tersebar pada PKBM di Kota Makassar. Pengambilan sampel dilakukan secara multi stage 
random sampling dengan mengikuti tahapan-tahapan sebagai berikut:

Pertama, dilakukan random terhadap PKBM di Kota Makassar yang akan dijadikan tempat menyelenggarakan pembelajaran yang menggunakan perlakuan penilaian di mana penelitian ini dilakukan. Kedua, secara random pula memilih satu kelompok untuk perlakuan penilaian portofolio dan satu kelompok untuk penilaian konvensional. Untuk lebih meyakinkan bahwa keadaan kelompok subjek yang dipilih sama untuk mendapatkan informasi awal tentang penyamaan warga belajar, dilakukan dengan pendekatan Participatory Rural Appraisal (PRA). Ketiga, menetapkan kelompok usia dari kedua kelas tersebut di atas berdasarkan hasil pengamatan dan identifikasi.

\section{Metode dan Desain Penelitian}

Metode yang digunakan dalam penelitian ini adalah metode eksperimen. Variabel penelitian terdiri atas: (1) variable bebas, dan (2) variable terikat. Adapun yang menjadi variabel bebas adalah jenis penilaian, dan tingkat usia. sedangkan variabel terikat adalah hasil belajar membaca dan hasil belajar menulis. Jenis penilaian hasil belajar yang merupakan variabel bebas atau variabel perlakuan, diklasifikasikan menjadi dua yaitu jenis penilaian portofolio dan jenis penilaian konvensional. Untuk variabel tingkatan usia warga belajar diklasifikasikan menjadi dua yaitu usia 15 tahun ke bawah dan usia di atas 15 tahun.

Desain yang digunakan dalam penelitian ini adalah "Disain Faktorial 2x2" dengan MANOVA (Multivariate Analysis of Variance) yang desainnya dalam matriks sebagai berikut:

Tabel 1. Desain Penelitian Eksperimen Faktorial 2x2

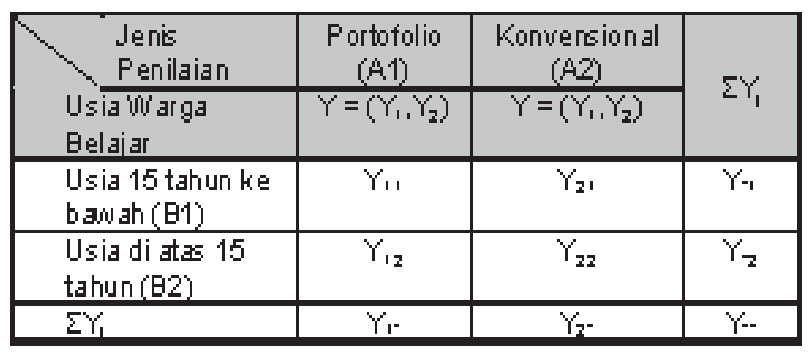

\section{Keterangan:}

$\mathrm{Y}=\left(\left(\mathrm{Y}_{1}, \mathrm{Y}_{2}\right)=\right.$ vektor nilai rata-rata

$Y_{1}=$ Hasil belajar membaca

$Y_{2}=$ Hasil belajar menulis

$\mathrm{A} 1=$ Warga belajar yang diberi penilaian portofolio

A2 = Warga belajar yang diberi penilaian konvensional

$\mathrm{B1}=$ Warga belajar usia 15 tahun ke bawah

B2 = Warga belajar usia di atas15 tahun
$Y_{11}=$ Vektor rata-rata kelompok yang diberi penilaian portofolio dan usia 15 tahun ke bawah

$\mathrm{Y}_{21}=$ Vektor rata-rata kelompok yang diberi penilaian konvensional dan usia 15 tahun ke bawah

$\mathrm{Y}_{12}=$ Vektor rata-rata kelompok yang diberi penilaian portofolio dan usia di atas 15 tahun

$Y_{22}=$ Vektor rata-rata kelompok yang diberi penilaian konvensional dan usia di atas 15 tahun

$Y_{* 1}=$ Vektor rata-rata kelompok usia 15 tahun ke bawah

$Y_{*_{2}}=$ Vektor rata-rata kelompok usia di atas 15 tahun

$Y_{1^{*}}=$ Vektor rata-rata kelompok yang diberi penila-

ian portofolio

$\mathrm{Y}_{2^{*}}=$ Vektor rata-rata kelompok yang diberi penilaian konvensional

$\mathrm{Y}_{* *}=$ Vektor rata-rata dari seluruh kelompok perlakuan.

\section{Teknik Pengumpulan Data}

Data yang dikumpulkan pada penelitian ini ada dua jenis data, yaitu: (1) data tentang hasil belajar membaca dan (2) data hasil belajar menulis. Sumber data primer untuk kedua jenis data tersebut adalah warga belajar pada satu periode pelaksanaan program. Data hasil belajar membaca dan data hasil belajar menulis dikumpulkan dengan menggunakan tes yang disertai dengan observasi.

Perlakuan terhadap warga belajar yang diberi perlakuan penilaian portofolio dan yang diberi perlakuan penilaian konvensional diberikan secara serentak dan sama, baik itu mengenai materi/pokok bahasan, jumlah pertemuan tatap muka, dan lama waktu tes. Dalam perlakuan tersebut, kecuali dalam penggunaan jenis penilaian yang berbeda yaitu antara yang diberi penilaian portofolio dan konvensional.

Pengukuran hasil belajar membaca dan hasil belajar menulis dilakukan setelah proses perlakuan eksperimen selesai dilakukan. Pengukuran tersebut dilakukan pada seluruh warga belajar baik itu kelompok usia 15 tahun ke bawah maupun usia di atas 15 tahun yang digunakan sebagai kelompok kovensional menggunakan tes hasil belajar membaca dan tes hasil belajar menulis yang disertai dengan observasi. Sedangkan penilaian pada kelompok portofolio dilakukan pada saat proses pembelajaran berlangsung.

\section{Teknik Analisis Data}

Pengolahan data mentah dari hasil penelitian menggunakan perhitungan manual dan bantuan komputer dengan program MS-Excel 2004 serta program SPSS versi 15. Dari pengolahan data mentah tersebut diketahui nilai masing-masing mean, median, modus, 
standar deviasi, range, minimum, maksimum, dan koefisien varians. Selanjutnya dibuat distribusi frekuensi yang divisualisasikan melalui tabel dan grafik.

Pengujian hipotesis penelitian menggunakan teknik Multivariate Analisis of Varians dua jalur (two-way MANOVA), dengan desain faktorial $2 \times 2$.
Pengujian lanjutan untuk membandingkan perbedaan pengaruh sederhana antara kelompok sebagai konsekuensi dari pengaruh interaksi bersifat signifikan dilakukan dengan menggunakan statistik uji $\mathrm{T}^{2}-\mathrm{Hot}$ telling yang hasilnya ditransformasi ke statistik uji $\mathrm{F}$.

\section{HASIL PENELITIAN}

Data tentang hasil belajar membaca dan hasil belajar menulis warga belajar diperoleh dari nilai yang dicapai warga belajar pada tes akhir setelah perlakuan dalam proses pembelajaran. Rekapitulasi skor hasil belajar membaca dan hasil belajar menulis semua kelompok perlakuan disajikan pada tabel berikut.

Tabel 2. Rekapitulasi Skor Hasil Belajar Membaca dan Menulis Semua Kelompok

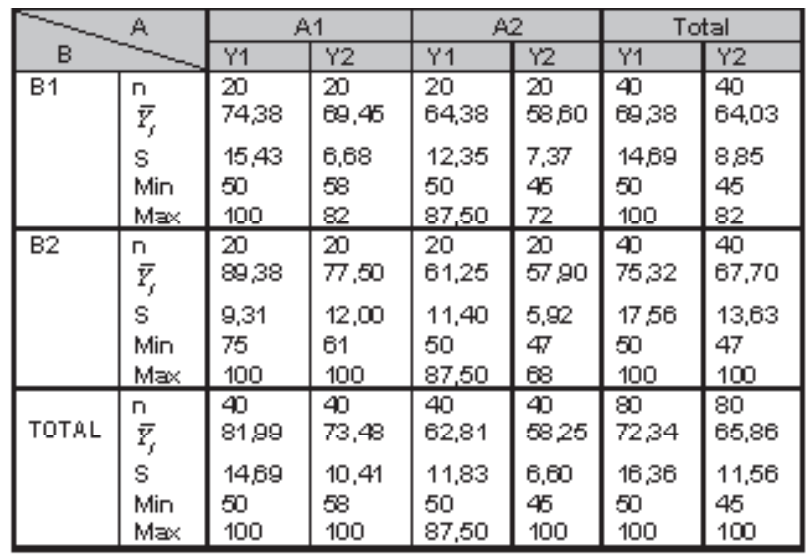

Keterangan:

$\mathrm{A} 1=$ Kelompok warga belajar yang diberi penilaian portofolio

A2 = Kelompok warga belajar yang diberi penilaian konvensional

B1 = Kelompok warga belajar usia 15 tahun ke bawah B2 = Kelompok warga belajar usia di atas 15 tahun $\eta_{\bar{Y}}=$ Banyaknya sampel untuk setiap kelompok

$Y_{j}=$ Skor rerata kriterion ke-j; $j=1,2$

$\mathrm{Y} 1=$ Hasil belajar membaca

$\mathrm{Y} 2=$ Hasil belajar menulis

\section{Pengujian Hipotesis Penelitian}

Hipotesis dalam penelitian ini secara inferensial diuji dengan menggunakan Analisis Varians Multivariat dua Jalur (Two Way Multivariate Analaysis of Varians = Two Way MANOVA). Analisis Varians Multivariat dua Jalur digunakan untuk menguji pengaruh utama (main effect) dan pengaruh interaksi (interaction ef$f e c t$ ). Ringkasan hasil pengujian hipotesis disajikan pada tabel berikut ini.
Tabel 3. Hasil Analisis Varians Multivariat (MANOVA) Dua Jalur

\begin{tabular}{|c|c|c|c|c|c|c|}
\hline Sumber & Matriks JK & & Lambda & $F$ & $F_{\text {butul }}$ & \\
\hline Varians & dan JHK & 00 & Wólks (스) & & 0,05 & 0,01 \\
\hline Antar A & 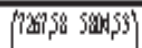 & & & & & \\
\hline & 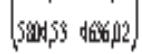 & 1 & 0,37 & $63,36^{x x}$ & 3,12 & 489 \\
\hline Antar B & $(705,08+31,41)$ & & & & & \\
\hline & $(436,+127,12)$ & 1 & 0,8 & $4,72^{x}$ & 3,12 & 489 \\
\hline hteraksi & $(162,58 \quad 992,9)$ & & & & & \\
\hline$A \times B$ & 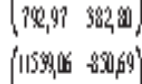 & 1 & 0,80 & $8,99^{x \pi}$ & 3,12 & 489 \\
\hline Dajam & 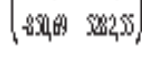 & 76 & & & & \\
\hline
\end{tabular}

Keterangan:

* = Signifikan pada $\alpha=0,05$

$* *$ Signifikan pada $\alpha=0,01$

Analisis terhadap uji lanjutan untuk menguji bagaimana bentuk interaksi yang terjadi dalam setiap tingkat perlakuan atau pengaruh sederhana (simple effect) dari setiap level perlakuan dilakukan dengan menggunakan statistik-uji $T^{2}$ Hotteling yang hasilnya ditransformasi ke statistik uji-F sebelum diambil kesimpulan. Ringkasan hasil pengujian lanjutan disajikan pada tabel berikut ini.

Tabel 4. Hasil Uji-Lanjutan dengan $T^{2}$ Hotteling

\begin{tabular}{|c|c|c|c|c|}
\hline \multirow{2}{*}{ Kelompok } & \multirow{2}{*}{$\mathrm{Db}$} & \multirow{2}{*}{$F$} & \multicolumn{2}{|c|}{$F_{\text {tan, } 1} \alpha=$} \\
\hline & & & 0,05 & 0,01 \\
\hline A181 dan A2B1 & $(2 ; 37)$ & $13,12^{x x}$ & 3,255 & 5,230 \\
\hline $\mathrm{A} 1 \mathrm{~B} 2 \mathrm{dan} \mathrm{A} 2 \mathrm{~B} 2$ & $(2 ; 37)$ & $50,38^{x x}$ & 3,255 & 5,230 \\
\hline A1B1 dan A1B2 & $(2 ; 37)$ & $46,11^{x \times x}$ & 3,255 & 5,230 \\
\hline A2B1 dan A2B2 & $(2 ; 37)$ & $12,51^{x x}$ & 3,255 & 5,230 \\
\hline
\end{tabular}

Berdasarkan hasil pengujian hipotesis seperti terangkum pada tabel di atas, maka dapat dijelaskan beberapa hal, sebagai berikut:

1. Perbedaan Hasil belajar Membaca dan Hasil Belajar Menulis antara Warga Belajar yang Diberi Penilaian Portofolio dan Warga Belajar yang Diberi Penilaian Konvensional

Hasil pengujian hipotesis dengan menggunakan 
teknik analisis MANOVA dua jalur, juga memperlihatkan bahwa ternyata $F$ observasi antar jenis penilaian atau $F_{(A)}=63,36$ lebih besar dari nilai $F_{\text {tabel }(0,01 ; 1 ; 76)}=$ 4,89 . Hal ini berarti bahwa data mendukung hipotesis. Dengan demikian terdapat perbedaan yang sangat signifikan hasil belajar membaca dan hasil belajar menulis antara warga belajar yang diberi penilaian portofolio dengan warga belajar yang diberi penilaian konvensional.

Secara multivariat nilai rata-rata hasil belajar membaca dan hasil belajar menulis kelompok 2 , A21 $={ }_{73,48}$ lebih tinggi dari pada kelompok A2 = 58,25$)$ . Dengan demikian hasil belajar membaca dan hasil belajar menulis warga belajar yang diberi penilaian portofolio lebih tinggi dari pada warga belajar yang diberi penilaian konvensional. Dengan kata lain rata-rata kelompok $\mathrm{A} 1$ > kelompok $\mathrm{A} 2$.

2. Perbedaan Hasil belajar Membaca dan Hasil Belajar Menulis antara Warga Belajar Usia 15 Tahun ke Bawah dengan Warga Belajar Usia Di Atas 15 Tahun

Hasil pengujian hipotesis dengan menggunakan teknik analisis MANOVA dua jalur, juga memperlihatkan bahwa ternyata F observasi antar tingkat usia atau $F_{(A)}=4,72$ lebih besar dari nilai $F_{\text {tabel }(0,05 ; 1 ; 76)}=3,12$. Hal ini berarti bahwa data mendukung hipotesis. Dengan demikian terdapat perbedaan yang signifikan hasil belajar membaca dan hasil belajar menulis antara warga belajar usia 15 tahun ke bawah dengan warga belajar usia di atas 15 tahun.

Secara multivariat nilai rata-rata hasil belajar membaca dan hasil belajar menulis kelompok, $\mathrm{B}_{2} 1$ $=(64,03$ lebih renda dari pada kelompok B2 = 67,70$)$

. Dengan demikian hasil belajar membaca dan hasil belajar menulis warga belajar usia 15 tahun ke bawah lebih renda dari pada warga belajar usia di atas 15 tahun. Dengan kata lain rata-rata kelompok B1 < kelompok B2.

3. Pengaruh Interaksi Usia dan Jenis Penilaian

Berdasarkan hasil analisis data dengan menggunakan MANOVA dua jalur seperti terangkum pada tabel 4.24 memperlihatkan bahwa nilai $F_{(A \times B)}$ observasi sebesar 8,99 ternyata jauh lebih besar dengan nilai $F_{\text {tabel }(0,01)}=4,89$; hal ini berarti bahwa data mendukung hipotesis. Dengan demikian hipotesis yang menyatakan ada pengaruh interaksi antara usia warga belajar dengan jenis penilaian terhadap hasil belajar membaca dan hasil belajar menulis warga belajar adalah bersifat sangat signifikan

Bentuk interaksi antara jenis penilaian dengan usia dari masing-masing variabel kriterion berturut-turut divisualkan pada gambar 1 dan gambar 2 sebagai berikut:

Membaca

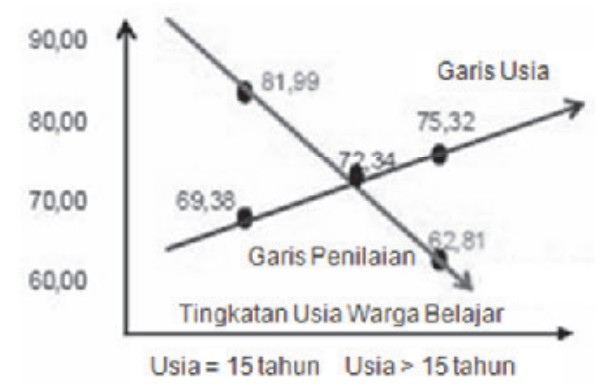

Gambar 1. Interaksi antara Jenis Penilaian dan Usia terhadap Hasil Belajar Membaca

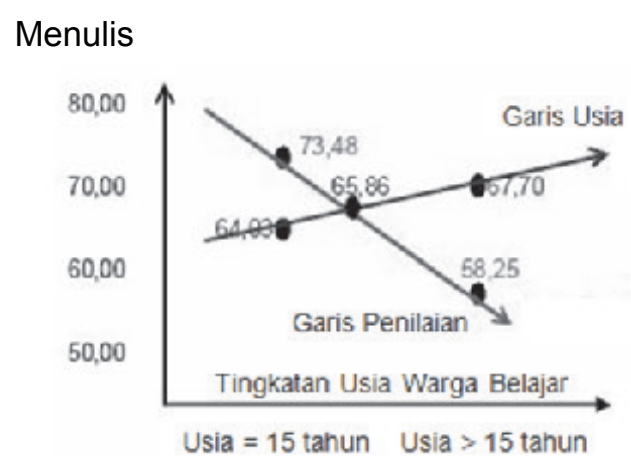

Gambar 2. Interaksi antara Jenis Penilaian dan Usia terhadap Hasil Belajar Menulis

4. Perbedaan Hasil belajar Membaca dan Hasil Belajar Menulis antara Warga Belajar Usia 15 Tahun ke Bawah yang Diberi Penilaian Portofolio dan Warga Belajar Usia 15 Tahun ke Bawah yang Diberi Penilaian Konvensional

Hasil pengujian hipotesis untuk melihat perbedaan antara warga belajar usia 15 tahun ke bawah yang diberi penilaian portofolio (A1B1) dan warga belajar usia 15 tahun ke bawah yang diberi penilaian konvensional (A2B1) menunjukkan bahwa nilai $F$ hasil transformasi $T^{2}-$ Hotteling ke statistik uji $F$, yaitu $F_{\text {hitung }}=$ 13,12 jauh lebih besar dari nilai $F_{\text {tabel }(0,01 ; 2 ; 37)}=5,23$. Hal ini berarti bahwa data mendukung hipotesis. Dengan demikian terdapat perbedaan yang sangat signifikan hasil belajar membaca dan hasil belajar menulis antara warga belajar usia 15 tahun ke bawah yang diberi penilaian portofolio dengan warga belajar usia 15 tahun ke bawah yang diberi penilaian konvensional. (74,38) Vektor nilai rata-rata kelompok A $(64,38)(69,45)$ lebih tinggi dari pada kelompok A2B1 = (58,60) Dengan demikian hasil belajar membaca dan hasil belajar menulis warga belajar usia 15 tahun ke bawah yang diberi penilaian portofolio lebih tinggi dari pada warga belajar usia 15 tahun ke bawah yang diberi penilaian konvensional. 
5. Perbedaan Hasil belajar Membaca dan Hasil Belajar Menulis antara Warga Belajar Usia Di Atas 15 Tahun yang Diberi Penilaian Portofolio dan Warga Belajar Usia Di Atas 15 Tahun yang Diberi Penilaian Konvensional

Hasil pengujian hipotesis untuk melihat perbedaan antara warga belajar usia di atas 15 tahun yang diberi penilaian portofolio (A1B2) dan warga belajar di atas 15 tahun yang diberi penilaian konvensional (A2B2) menunjukkan bahwa nilai $F$ hasil transformasi $T^{2}$ - Hotteling ke statistik uji $F$, yaitu $F_{\text {hitung }}=50,38$ jauh lebih besar dari nilai $F_{\text {tabel }(0,01 ; 2 ; 37)}=5,23$. Hal ini berarti bahwa data mendukung hipotesis. Dengan demikian terdapat perbedaan yang sangat signifikan hasil belajar membaca dan hasil belajar menulis antara warga belajar usia di atas 15 tahun yang diberi penilaian portofolio dengan warga belajar di atas 15 tahun yang diberi penilaian konvensional.

Vektor nilai rata-rata kelompok A1BR2 5 (77,50) lebih tinggi dari pada kelompok A2B2 $=(57,90)$ Dengan demikian hasil belajar membaca dan hasil belajar menulis warga belajar usia di atas 15 tahun yang diberi penilaian portofolio lebih tinggi dari pada warga belajar usia di atas 15 tahun yang diberi penilaian konvensional.

6. Perbedaan Hasil belajar Membaca dan Hasil Belajar Menulis antara Warga Belajar Usia 15 Tahun ke Bawah yang Diberi Penilaian Portofolio Dengan Warga Belajar Usia Di Atas 15 Tahun yang Diberi Penilaian Portofolio

Hasil pengujian hipotesis untuk melihat perbedaan antara warga belajar usia 15 tahun ke bawah yang diberi penilaian portofolio (A1B1) dan warga belajar usia di atas 15 tahun yang diberi penilaian portofolio (A1B2) menunjukkan bahwa nilai $F$ hasil transformasi $T^{2}$ - Hotteling ke statistik uji $F$, yaitu $F_{\text {hitung }}=46,11$ jauh lebih besar dari nilai $F_{\text {tabel }(0,01 ; 2 ; 37)}=5,23$. Hal ini berarti bahwa data mendukung hipotesis. Dengan demikian terdapat perbedaan yang sangat signifikan hasil belajar membaca dan hasil belajar menulis antara warga belajar usia di bawah 15 tahun ke bawah yang diberi penilaian portofolio dengan warga belajar usia di atas 15 tahun yang diberi penilaian portofolio.

Vektor nilai rata-rata kelompok $\mathrm{A} 1 \mathrm{~B} 1=(61,25)$, lebih rendah dari pada kelompok A1B2 $=(57,90)$. Dengan demikian hasil belajar membaca dan hasil belajar menulis warga belajar usia di atas 15 tahun yang diberi penilaian portofolio lebih tinggi dari pada warga belajar usia 15 tahun ke bawah yang diberi penilaian portofolio.

7. Perbedaan Hasil belajar Membaca dan Hasil Belajar Menulis antara Warga Belajar Usia 15 Tahun ke Bawah yang Diberi Penilaian Konvensional Dengan Warga Belajar Usia Di Atas 15 Tahun yang Diberi Penilaian Konvensional

Hasil pengujian hipotesis untuk melihat perbedaan antara warga belajar usia 15 tahun ke bawah yang diberi penilaian konvensional (A2B1) dan warga belajar usia di atas 15 tahun yang diberi penilaian konvensional (A2B2) menunjukkan bahwa nilai $F$ hasil transformasi $T^{2}-$ Hotteling ke statistik uji $\mathrm{F}$, yaitu $\mathrm{F}_{\text {hitung }}=$ 12,51 jauh lebih besar dari nilai $F_{\text {tabel }(0,01 ; ; 2 ; 7)}=5,23$. Hal ini berarti bahwa data mendukung hipotesis. Dengan demikian terdapat perbedaan yang sangat signifikan hasil belajar membaca dan hasil belajar menulis antara warga belajar usia 15 tahun ke bawah yang diberi penilaian konvensional dengan warga belajar usia di atas 15 tahun yang diberi penilaian konvensional.

Vektor nilai rata-rata kelompok A2B1 = lebih tinggi dari pada kelompok A2B2 = Dengan demikian hasil belajar membaca dan hasil

belajar menulis warga belajar usia 15 tahun ke bawah yang diberi penilaian konvensional lebih tinggi dari pada warga belajar usia di atas 15 tahun yang diberi penilaian konvensional.

\section{HASIL PENELITIAN}

Tujuan umum dari penelitian ini adalah untuk memperoleh hasil belajar yang lebih lengkap meliputi hasil belajar membaca dan hasil belajar menulis. Kedua variabel dependen ini dicoba ditingkatkan melalui pemberian model penilaian portofolio dan model penilaian formatif baik warga belajar yang berusia 15 tahun ke bawah maupun usia di atas 15 tahun. Kombinasi dari level tertentu dari model penilaian dengan level tertentu dari tingkatan usia akan dibahas berdasarkan temuan dan hasil pengujian hipotesis sebagai berikut:
1. Perbedaan Hasil Belajar Membaca dan Hasil Belajar Menulis antara Warga Belajar yang Diberi Penilaian Portofolio dan Warga Belajar yang Diberi Penilaian Konvensional

Hipotesis yang menyatakan "Hasil belajar membaca dan hasil belajar menulis warga belajar yang diberi penilaian portofolio lebih tinggi dari pada warga belajar yang diberi penilaian konvensional" ternyata secara empiris teruji oleh data. Hal ini berarti bahwa agar warga belajar memiliki hasil belajar membaca dan hasil belajar menulis yang lebih baik maka lebih 
efektif bila warga belajar diberi penilaian portofolio dari pada penilaian konvensional. Kebenaran teoritis dan kenyataan empiris ini adalah relevan dengan rasional dari tujuan pembelajaran keaksaraan bagi warga belajar yakni terdapatnya keserasian antara pembelajaran yang menekankan pada konsep yang telah dibelajarkan dengan keterampilan fungsional dalam kehidupan sehari-hari. Hal ini sejalan dengan pendapat Kusnadi (2005: 136), bahwa pendidikan keaksaraan dikembangkan dalam rangka meningkatkan keaksaraan dasar warga masyarakat buta aksara sesuai dengan minat dan kebutuhan belajarnya, dan membelajarkan warga masyarakat buta aksara, agar mampu membaca, menulis, dan berhitung, mampu berbahasa Indonesia, memiliki pengetahuan dan keterampilan dasar yang dapat meningkatkan mutu dan taraf hidupnya.

Dalam penelitian ini penilaian portofolio memberikan kesempatan untuk melakukan refleksi bersama-sama, dimana warga belajar dapat merefleksikan tentang proses berpikir mereka sendiri, tentang kemampuan pemahaman mereka sendiri, pemecahan masalah atau pengambilan keputusan, dan mengamati pemahaman mereka tentang kompetensi dasar dan indikator yang telah mereka peroleh. Oleh karena itu penilaian portofolio yang diberikan kepada warga belajar dalam penelitian ini bertujuan untuk menilai proses langkah-langkah, dan strategi yang ditempuh warga belajar dalam menyelesaikan masalah hingga menemukan jawaban soal dan bukan hanya pada hasil akhir dari jawaban. Penilaian portofolio yang diberikan kepada warga belajar sesuai dengan rumusan beberapa prinsip dari Thorndike (Sardiman, 2000:34) antara lain "law of exercise" atau "hukum latihan". Berdasarkan hukum tersebut maka hubungan antara stimulus dengan respon akan bertambah erat jika sering dilatih, diulangi atau dipakai dan akan berkurang bahkan lenyap jika jarang atau tidak pernah dilatih, diulangi atau digunakan. Oleh karena itu agar proses belajar dapat berlangsung dengan hasil maksimal maka warga belajar perlu sering diberikan latihan atau ulangan.

Di lain pihak, penilaian konvensional adalah salah satu jenis penilaian warga belajar di satuan pendidikan luar sekolah yang dilaksanakan secara berkelanjutan pada akhir setiap pembahasan kompetensi dasar tertentu, dimaksudkan untuk mengetahui sejauh mana warga belajar telah menguasai kompetensi dasar yang telah ditentukan sebelumnya. Akhir setiap kompetensi dasar adalah merupakan pernyataan minimal atau memdai tentang pengetahuan, keterampilan, sikap dan nilai-nilai yang direfleksikan dalam kebiasaan berpikir dan bertindak setelah warga belajar menyelesaikan suatu aspek atau sub aspek mata pelajaran tertentu. Penilaian konvensional setiap kompetensi dasar sama dengan ulangan harian yaitu suatu ulangan yang dilakukan setiap selesai proses pembelajaran dalam satuan bahasan atau kompetensi dasar tertentu dan biasanya dilakukan minimal tiga kali dalam setiap semester.

Dengan menelaah variabel tolak ukur penelitian yang lebih bersifat proses dan permanen maka warga belajar yang diberi penilaian portofolio lebih berpeluang untuk mencapai hasil belajar membaca dan hasil belajar menulis yang lebih tinggi dari pada warga belajar yang diberi penilaian konvensional.

Kebenaran alasan di atas didukung oleh fakta empiris yakni bahwa pencapaian nilai rata-rata hasil belajar membaca warga belajar yang diberi penilaian portofolio secara signifikan lebih tinggi dari pada warga belajar yang diberi penilaian konvensional (81,99 > $62,81)$. Begitupula nilai rata-rata hasil belajar menulis warga belajar yang diberi penilaian portofolio juga secara signifikan lebih tinggi dari pada warga belajar yang diberi penilaian konvensional $(73,48>58,25)$. Kebenaran ini merupakan suatu bukti empiris bahwa pemberian penilaian portofolio ternyata lebih efektif dari pada pemberian penilaian konvensional. Adanya kelompok pembanding yaitu pemberian penilaian konvensional merupakan bukti nyata bahwa hasil yang dicapai memang pengaruh dari pemberian penilaian portofolio. Temuan ini sejalan dengan teori yang melandasi masing-masing variabel penelitian. Dengan demikian hipotesis yang dikemukakan adalah benar dan ternyata teruji oleh data. Sehingga hasil belajar membaca dan hasil belajar menulis warga belajar yang diberi penilaian portofolio lebih tinggi dari pada warga belajar yang diberi penilaian konvensional.

2. Perbedaan Hasil Belajar Membaca dan Hasil Belajar Menulis antara Warga Belajar Usia 15 Tahun ke Bawah dan Warga Belajar Usia Di Atas 15 Tahun

Hipotesis yang menyatakan "Hasil belajar membaca dan hasil belajar menulis warga belajar yang berusia di atas 15 tahun lebih tinggi dari pada warga belajar yang berusia 15 tahun ke bawah" ternyata secara empiris teruji oleh data. Hal ini berarti bahwa warga belajar yang berusia di atas 15 tahun lebih efektif untuk mencapai hasil belajar membaca dan hasil belajar menulis dari pada warga belajar yang berusia 15 tahun ke bawah.

Warga belajar yang berusia 15 tahun ke atas merupakan usia dewasa atau suatu bagian dari proses yang berkelanjutan dari masa usia 15 tahun. Keadaan yang dialami orang dewasa sekarang ini merupakan masa bagi seseorang untuk memantapkan kemamp- 
uan dan keterampilan dasar yang telah diperolehnya di masa usia kanak-kanak. Pada usia dewasa kemampuan dan keterampilan dasar yang telah diperoleh, selain dimantapkan, juga dikembangkan sehingga makin banyak pengetahuan dan keterampilan baru yang diperoleh, yang pada gilirannya akan makin lebih mantap dalam belajar lebih lanjut. Hal ini sejalan dengan pendapat Darkenwald and Mariam (1982) bahwa prinsip-prinsip pembelajaran orang dewasa: (1) Kesiapan belajar orang dewasa tergantung pada kuantitas pembelajaran yang sudah ada sebelumnya, (2) Reinforcement (penguatan) positif lebih efektif, (3) Motivasi instrinsik menghasilkan pembelajaran lebih mudah diserap dan lebih prmanen, (4) Bahan belajar akan lebih mudah dipelajari apabila sesuai dengan kebiasaannya, (5) Belajar akan lebih baik bila dilakukan dengan pengulangan (trial and error), (6) Bahan belajar dan tugas yang bermakna bagi kehidupannya akan lebih mudah untuk dipelajari, (7) Partisipasi aktif dalam pembelajaran akan memperbaiki ingatan, dan (8) Faktor lingkungan mempengaruhi pembelajaran (Kusnadi, 2005: 105).

Warga belajar yang berusia di atas 15 tahun kemampuan dan keterampilan dasar yang telah diperoleh, selain dimantapkan, juga dikembangkan sehingga makin banyak pengetahuan dan keterampilan baru yang diperoleh, yang pada gilirannya akan makin lebih mantap dalam belajar lebih lanjut. Hal ini sesuai dengan pendapat Knowles (1984) bahwa (a) orang dewasa berbeda dengan anak-anak dalam hal sikap hidup, pandangan terhadap nilai-nilai hidup, minat, kebutuhan, ide/gagasan, hasrat-hasrat dan dorongan untuk melakukan suatu perbuatan, (b) orang dewasa sudah banyak memiliki pengalaman-pengalaman hidup (lebih banyak daripada anak-anak), maka mereka pada umumnya tidak mudah diubah sikap hidupnya, (c) orang dewasa mempunyai konsep diri yang kuat dan mempunyai kebutuhan untuk mengatur dirinya sendiri, oleh karena itu mereka cenderung menolak apabila dibawa ke dalam situasi yang digurui atau diperlakukan seperti anak-anak, (d) pengalaman merupakan sumber yang paling kaya dalam proses belajar orang dewasa, oleh karena itu inti metodologi proses belajar orang dewasa adalah menganalisis pengalaman, (e) pada umumnya tidak ada perbedaan pada tingkat kecerdasan dan kemampuan belajar antar orang dewasa dan anak-anak, bila ada perbedaan mungkin hanya terjadi antara individu yang satu dengan individu yang lainnya, (f) orang dewasa akan lebih cepat dan lebih mudah menerima dan memahami isi pelajaran atau pendidikan, apabila ia telah dapat menyadari dan menginsafi manfaat dan pentingnya pelajaran dan pendidikan itu bagi kehidupan, dan (g) orang dewasa akan lebih mudah memahami suatu hal apabila dapat diterapkannya melalui berbagai jenis pancaindera (penglihatan, pendengaran, perasaan dan lain-lain), lebih-lebih apabila dihayati dengan jalan melakukannya sendiri (Kusnadi, 2005: 103).

Temuan penelitian yang mengungkap bahwa warga belajar yang berusia di atas 16 tahun pencapaian nilai rata-rata hasil belajar membaca secara signifikan lebih tinggi dari pada warga belajar yang berusia 15 tahun ke bawah $(75,32>69,38)$. Begitupula warga belajar yang berusia di atas 15 tahun pencapaian nilai rata-rata hasil belajar menulis juga secara signifikan lebih tinggi dari pada warga belajar yang berusia 15 tahun ke bawah $(67,70>64,03)$. Kebenaran temuan ini merupakan suatu bukti empiris bahwa warga belajar yang berusia di atas 15 tahun lebih efektif untuk mencapai hasil belajar membaca dan hasil belajar menulis dari pada warga belajar yang berusia 15 tahun ke bawah. Temuan ini sejalan dengan teori yang melandasi masing-masing variabel penelitian. Dengan demikian hipotesis yang dikemukakan adalah benar teruji oleh data. Sehingga hasil belajar membaca dan hasil belajar menulis warga belajar yang berusia di atas 15 tahun lebih tinggi dari pada warga belajar yang berusia 15 tahun ke bawah.

3. Pengaruh Interaksi antara Model Penilaian dan Tingkat Usia Terhadap Hasil Bealajar Membaca dan Hasil Bealajar Menulis

Pengaruh interaksi bersifat signifikan antara model penilaian dengan tingkat usia menunjukkan bahwa hipotesis tentang interaksi secara empiris ternyata teruji oleh data. Ini berarti perbedaan hasil belajar membaca dan menulis ditentukan oleh model penilaian dengan tinkat usia. Signifikansi interaksi ini akan berimplikasi terhadap bentuk interaksi yang nterjadi. Artnya pengaruh interaksi akan mempunyai makna penting jika dilakukan pengujian pada efek-efek sederhana dari setiap tingkat perlakuan. Dengan MANOVA dua jalur, maka terdapat empat efek (pengaruh) sederhana: (1) Pengaruh sederhana faktor model penilaian untuk usia 15 tahun ke bawah, (2) Pengaruh sederhana faktor model penilaian untuk usia di atas 15 tahun, (3) Pengaruh sederhana faktor tingkat usia untuk model penilaian portofolio, dan (4) Pengaruh sederhana faktor tingkat usia untuk model penilaian konvensional. Pembahasan ke empat pengaruh sederhana tersebut diuraikan sebagai berikut.

4. Perbedaan Hasil belajar Membaca dan Hasil Belajar Menulis antara Warga Belajar Usia 15 Tahun ke Bawah yang Diberi Penilaian Portofolio dan Warga Belajar Usia 15 Tahun ke Bawah yang Diberi 


\section{Penilaian Konvensional}

Hipotesis penelitian yang menyatakan bahwa "untuk warga belajar yang berusia 15 tahun ke bawah hasil belajar membaca dan menulis warga belajar yang diberi penilaian portofolio lebih tinggi daripada warga belajar yang diberi penilaian konvensional" ternyata secara empiris teruji oleh data. Hal ini menunjukkan bahwa untuk warga belajar yang usia 15 tahun ke bawah, hasil belajar membaca dan hasil belajar menulis warga belajar hasilnya akan lebih efektif bila warga belajar diberi penilaian portofolio daripada penilaian konvensional. Temuan ini dapat dijelaskan dari karakteristik yang dimiliki oleh model penilaian portofolio yang didukung oleh karakteristik warga belajar yang usia 15 tahun ke bawah. Inti dari model penilaian portofolio adalah digunakan sebagai alat pengajaran dan juga sebagai alat penilaian.

Penilaian portofolio merupakan proses penilaian yang berlangsung dua arah antara tutor dan warga belajar lainnya. Dalam penilaian portofolio antara tutor dan warga belajar memiliki rasa saling mempercayai, saling memerlukan, dan memiliki semangat untuk saling membantu. Oleh karena itu, antara tutor dan warga belajar harus saling terbuka dan jujur satu sama lain. Tutor hendaknya seoptimal mungkin menciptakan suasana pembelajaran dan penilaian yang kondusif sehingga warga belajar dapat dengan mudah memperlihatkan kemampuannya secara optimal baik itu kemampuan membaca maupun kemampuan menulis yang sesuai dengan harapan standar kompetensi, kompetensi dasar, dan indikator yang ditutut dalam kurikulum. Hal ini sejalan dengan pendapat Sumarno Surapranata dan Muhammad Hatta (2004) mengartikan penilaian berbasis kelas merupakan proses pengumpulan dan pengunaan informasi dan hasil belajar peserta didik yang dilakukan guru untuk menetapkan tingkat pencapaian dan penguasaan peserta didik terhadap tujuan pendidikan yang telah ditetapkan, yaitu standar kompetensi, kompetensi dasar, dan indikator pencapaian belajar yang terdapat dalam kurikulum.

Karakteristik penilaian portofolio di atas didukung oleh tingkatan usia warga belajar yang berusia 15 tahun ke bawah, yaitu pada kelompok umur tersebut, warga belajar memperlihatkan adanya suatu masa transisi utama dalam proses berpikir. Kelompok umur tersebut warga belajar telah mampu berpikir abstrak, menggunakan berbagai teori, dan menggunakan berbagai hubungan logis tanpa harus menunjuk pada hal-hal yang konkret. Tahapan opersi formal ini merupakan landasan yang memungkinkan anak melakukan pemecahan berbagai masalah.

Temuan penelitian bahwa nilai rata-rata hasil belajar membaca dari warga belajar yang diberi penilaian portofolio secara signifikan lebih tinggi dari pada warga belajar yang diberi penilaian konvensional $(74,38>64,38)$. Begitupula nilai rata-rata hasil belajar menulis dari warga belajar yang diberi penilaian portofolio secara signifikan lebih tinggi dari pada warga belajar yang diberi penilaian konvensional $(69,45>$ $58,60)$ merupakan suatu bukti empiris bahwa kombinasi penilaian portofolio dengan tingkatan usia warga belajar 15 tahun ke bawah ternyata lebih efektif dari pada kombinasi penilaian konvensional dengan tingkatan usia warga belajar 15 tahun ke bawah. Adanya kelompok pembanding berupa, pemberian penilaian konvensional dengan tingkatan usia 15 tahun ke bawah merupakan konsekuensi logis bahwa hasil yang dicapai memang pengaruh dari kombinasi perlakuan. Temuan ini sejalan dengan teori yang melandasi masing-masing variabel eksperimen. Dengan demikian hipotesis yang dikemukakan adalah benar dan ternyata teruji oleh data. Sehingga untuk warga belajar yang usia 15 tahun ke bawah hasil belajar membaca dan menulis warga belajar yang diberi penilaian portofolio lebih tinggi dari pada warga belajar yang diberi penilaian konvensional.

5. Perbedaan Hasil belajar Membaca dan Hasil Belajar Menulis antara Warga Belajar Usia Di Atas 15 Tahun yang Diberi Penilaian Portofolio dan Warga Belajar Usia Di Atas 15 Tahun yang Diberi Penilaian Konvensional

Hipotesis penelitian yang menyatakan bahwa "untuk warga belajar yang berusia di atas 15 tahun hasil belajar membaca dan menulis warga belajar yang diberi penilaian portofolio lebih tinggi daripada warga belajar yang diberi penilaian konvensional" ternyata secara empiris teruji oleh data. Hal ini menunjukkan bahwa untuk warga belajar yang usia di atas 15 tahun, hasil belajar membaca dan hasil belajar menulis warga belajr hasilnya akan lebih efektif bila warga belajar diberi penilaian portofolio dari pada penilaian konvensional. Temuan ini dapat dijelaskan dari karakteristik yang dimiliki oleh penilaian portofolio yang akan lebih kondusif bila didukung oleh usia warga belajar yang di atas 15 tahun. Inti dari penilaian portofolio adalah digunakan sebagai alat pengajaran dan juga sebagai alat penilaian.

Penilaian portofolio memberikan kesempatan untuk melakukan refleksi bersama-sama, dimana warga belajar dapat merefleksikan tentang proses berpikir mereka sendiri, tentang kemampuan pemahaman mereka sendiri, pemecahan masalah atau pengambilan keputusan, dan mengamati pemahaman mereka tentang kompetensi dasar dan indikator yang 
telah mereka peroleh. Sejalan yang diungkapkan oleh Surapratana dan Hatta (2004) sebagai berikut: portofolio diartikan sebagai kumpulan hasil evidence atau hasil belajar atau karya peserta didik yang menunjukkan usaha, perkembangan, prestasi belajar peserta didik dari waktu ke waktu dan dari satu mata pelajaran ke pelajaran yang lain.

Warga belajar yang memiliki usia di atas 15 tahun dapat dikelompok pada kelompok orang dewasa. Kelompok umur tersebut akan termotivasi untuk belajar karena kebutuhan dan minat dimana belajar akan memberikan kepuasan, orientasi pembelajaran kelompok usia tersebut adalah berpusat kepada kehidupan nyata, pengalaman sebagai sumber terbaik bagi kelompok umur tersebut. Perbedaan diantara warga belajar usia di atas 15 tahun semakin meningkat dengan bertambahnya usia, oleh karena itu memberi pilihan dalam hal perbedaan gaya belajar dan jenis penilaian yang digunakan. Dengan demikian bahwa, sebagai efek dari perlakuan penggunaan penilaian portofolio, adalah semakin bertambahnya usia warga belajar maka semakin baik hasil belajar membaca dan menulis yang diperoleh warga belajar.

Fakta yang mendukung alasan di atas adalah bahwa ternyata pencapaian nilai rata-rata hasil belajar membaca warga belajar usia di atas 15 tahun yang diberi penilaian portofolio secara signifikan lebih tinggi dari pada warga belajar usia di atas 15 tahun yang diberi penilaian konvensional $(89,38>61,25)$. Begitu pula nilai rata-rata hasil belajar menulis warga belajar usia di atas 15 tahun yang diberi penilaian portofolio juga secara signifikan lebih tinggi dari pada warga belajar usia di atas 15 tahun yang diberi penilaian konvensional $(77,50>57,90)$. Kebenaran ini merupakan suatu bukti empiris bahwa kombinasi perlakuan penilaian portofolio dengan usia warga belajar yang di atas 15 tahun ternyata lebih efektif dari pada kombinasi penilaian konvensional dengan usia warga belajar di atas 15 tahun. Adanya kelompok pembanding berupa, pemberian penilaian konvensional untuk usia warga belajar di atas 15 tahun merupakan konsekuensi logis bahwa hasil yang dicapai memang pengaruh dari kombinasi perlakuan antara penilaian portofolio dengan usia di atas 16 tahun. Temuan ini sejalan dengan teori yang melandasi masing-masing variabel penelitian. Dengan demikian hipotesis yang dikemukakan adalah benar dan ternyata teruji oleh data. Sehingga untuk warga belajar usia di atas 15 tahun, hasil belajar membaca dan menulis warga belajar yang diberi penilaian portofolio lebih tinggi dari pada warga belajar yang diberi penilaian konvensional.

6. Perbedaan Hasil belajar Membaca dan Hasil Be- lajar Menulis antara Warga Belajar Usia 15 Tahun ke Bawah yang Diberi Penilaian Portofolio Dengan Warga Belajar Usia Di Atas 15 Tahun yang Diberi Penilaian Portofolio

Hipotesis penelitian yang menyatakan bahwa " Untuk warga belajar yang diberi penilaian portofolio, hasil belajar membaca dan hasil belajar menulis warga belajar yang berusia di atas 15 tahun lebih tinggi daripada warga belajar yang berusia 15 tahun ke bawah" ternyata teruji oleh data. Hal ini berarti bahwa untuk mencapai hasil belajar membaca dan menulis yang lebih baik maka warga belajar usia di atas 15 tahun lebih efektif diberi penilaian portofolio dari pada warga belajar usia 15 tahun ke bawah.

Keberhasilan warga belajar usia di atas 15 tahun yang diberi penilaian portofolio, terkait dengan sifat subyek dan interaksi belajar mengajar yang terjadi pada penilaian portofolio itu sendiri. Program belajar yang berpusat pada masalah mengarahkan pengalaman belajar pada masalah yang dihadapi oleh warga belajar dalam kehidupan sehari-hari, dengan maksud untuk memperlihatkan kepada mereka bahwa pengetahuan yang diperoleh erat kaitannya dengan kegunaan dan masalah yang dihadapinya. Hal sesuai dengan pendapat Gibb yang dikutip oleh Brooksfield (1986) bahwa prinsip-prinsip belajar orang dewasa yaitu (1) Pembelajaran harus berorientasi pada masalah (problem oriented); (2) Pembelajaran harus berorientasi pada pengalaman sendiri warga belajar (experiences oriented); (3) Pengalaman harus penuh makna (meaningfull) bagi warga belajar, (4) warga belajar bebas untuk belajar sesuai dengan pengalamannya; (5) tujuan belajar harus ditentukan dan disetujui oleh warga belajar melalui kontrak belajar (learning contract); dan (6) warga belajar harus memperoleh umpan balik tentang pencapaian tujuan.

Dengan hasil belajar membaca dan menulis dari warga belajar usia di atas 16 tahun yang menggunakan penilaian portofolio ini warga belajar mengelola dan mengontrol serta mengevaluasi informasi dari masalah atau tugas yang mungkin saja terbatas tetapi perlu diterapkan secara tepat. Dengan kata lain bahwa memiliki segudang pengetahuan saja tidak cukup tanpa memiliki kemampuan memilih secara tepat, mengorganisasikan, dan menggunakannya dalam pemecahan masalah. Sebaliknya warga belajar usia 15 tahun ke bawah kurang memperoleh kesempatan untuk sampai pada kesadaran mengelola dan mengontrol serta mengevaluasi informasi dari masalah.

Temuan penelitian bahwa nilai rata-rata hasil belajar membaca warga belajar usia di atas 15 tahun yang diberi penilaian portofolio yang secara signifikan 
lebih tinggi dari pada warga belajar usia 15 tahun ke bawah yang diberi penilaian portofolio $(89,38>74,38)$. Begitupula nilai rata-rata hasil belajar menulis warga belajar usia di atas 15 tahun yang diberi penilaian portofolio juga secara signifikan lebih tinggi dari pada warga belajar usia 15 tahun ke bawah yang diberi penilaian portofolio $(77,50>69,45)$. Kebenaran ini merupakan suatu bukti empiris bahwa kombinasi perlakuan antara penilaian portofolio denga usia warga belajar di atas 15 tahun ternyata lebih efektif dari pada kombinasi antara penilaian portofolio dengan usia warga belajar 15 tahun ke bawah. Adanya kelompok pembanding yaitu warga belajar usia 15 tahun ke bawah yang diberi penilaian portofolio merupakan konsekuensi logis bahwa hasil yang dicapai memang pengaruh dari perlakuan. Temuan ini sejalan dengan teori yang melandasi masing-masing variabel eksperimen. Dengan hipotesis yang dikemukakan adalah benar teruji oleh data. Sehingga hasil belajar membaca dan menulis warga belajar usia di atas 15 tahun yang diberi penilaian portofolio lebih tinggi dari pada warga belajar usia 15 tahun ke bawah yang diberi penilaian portofolio.

7. Perbedaan Hasil belajar Membaca dan Hasil Belajar Menulis antara Warga Belajar Usia 15 Tahun ke Bawah yang Diberi Penilaian Konvensional Dengan Warga Belajar Usia Di Atas 15 Tahun yang Diberi Penilaian Konvensional

Hipotesis penelitian yang menyatakan " Untuk warga belajar yang diberi penilaian konvensional, hasil belajar membaca dan hasil belajar menulis warga belajar yang berusia 15 tahun ke bawah lebih tinggi daripada warga belajar yang berusia di atas 15 tahun" ternyata secara empiris teruji oleh data. Hal ini menunjukkan bahwa untuk mencapai hasil belajar membaca dan hasil belajar menulis yang lebih baik maka warga belajar usia 15 tahun ke bawah lebih efektif diberi penilaian konvensional dari pada warga belajar usia di atas 15 tahun. Temuan ini terkait dengan sifat subyek dan proses belajar mengajar yang terjadi pada warga belajar usia 15 tahun ke bawah. Menurut pandangan behaviorisme, belajar adalah perubahan dalam tingkah laku sebagai akibat dari interaksi antara stimulus dan respon (Irawan, Suciati, dan Wardani, 1997: 2). Mengenai hubungan antara stimulus dan respon tersebut E.L. Thorndike merumuskan beberapa prinsip atau hukum antara lain "law of exercise" atau "hukum latihan". Berdasarkan hukum tersebut maka hubungan antara stimulus dengan respon akan bertambah erat jika sering dilatih, diulangi atau dipakai dan akan berkurang bahkan lenyap jika jarang atau tidak pernah dilatih, diulangi atau digunakan (Sardiman, 2000: 34). Oleh karena itu agar proses belajar dapat berlangsung dengan hasil maksimal maka seseorang perlu sering diberikan latihan atau ulangan dalam hal ini penilaian konvensional.

Proses belajar terjadi apabila terjadi proses pengolahan data yang aktif dari pihak yang belajar. Pengolahan data yang aktif tersebut merupakan aktivitas lanjutan dari kegiatan mencari informasi dan dilanjutkan dengan kegiatan-kegiatan penemuan. Berdasarkan pandangan tersebut warga belajar usia 15 tahun ke bawah dianggap sebagai subyek belajar yang aktif yang dapat menimbulkan stimulasi bagi dirinya, mencari jawaban terhadap stimulasi tersebut, serta mengembangkan stimulasi baru untuk hal-hal yang baru. Proses belajar seperti ini akan berlangsung dengan baik apabila yang dipelajari sesuai dengan perkembangan kognitif yang belajar. Dengan demikian secara deskriptif makin tinggi frekuensi penilaian maka semakin baik pula hasil belajar membaca dan menulis warga belajar sebagai efek dari perlakuan.

Kebenaran uraian di atas didukung oleh pencapaian nilai rata-rata hasil belajar membaca warga belajar usia 15 tahun ke bawah yang diberi penilaian konvensional secara signifikan lebih tinggi dari pada warga belajar usia di atas 15 tahun yang diberi penilaian konvensional $(64,38>61,25)$. Begitupula nilai rata-rata hasil belajar menulis warga belajar usia 15 tahun ke bawah yang diberi penilaian konvensional juga secara signifikan lebih tinggi dari pada warga belajar usia di atas 15 tahun yang diberi penilaian konvensional $(58,60>57,90)$. Kebenaran ini merupakan suatu bukti empiris bahwa kombinasi perlakuan antara penilaian konvensional dengan usia warga belajar 15 tahun ke bawah ternyata lebih efektif dari pada kombinasi antara penilaian konvensional dengan usia warga belajar di atas 15 tahun. Adanya kelompok pembanding yaitu warga belajar usia di atas 15 tahun yang diberi penilaian konvensional merupakan konsekuensi logis bahwa hasil yang dicapai memang pengaruh dari perlakuan. Temuan ini sejalan dengan teori yang melandasi masing-masing variabel eksperimen. Dengan hipotesis yang dikemukakan adalah benar teruji oleh data. Sehingga hasil belajar membaca dan menulis warga belajar usia 15 tahun ke bawah yang diberi penilaian konvensional lebih tinggi dari pada warga belajar usia di atas 15 tahun yang diberi penilaian konvensional. 


\section{KESIMPULAN}

1. Hasil belajar membaca dan hasil belajar menulis warga belajar yang diberi penilaian portofolio lebih tinggi daripada warga belajar yang diberi penilaian konvensional.

2. Hasil belajar membaca dan hasil belajar menulis warga belajar yang berusia di atas 15 tahun lebih tinggi daripada warga belajar yang berusia 15 tahun ke bawah

3. Terdapat pengaruh interaksi antara jenis penilaian dengan tingkatan usia terhadap hasil belajar membaca dan hasil belajar menulis

4. Untuk warga belajar yang berusia 15 tahun ke bawah, hasil belajar membaca dan hasil belajar menulis warga belajar yang diberi penilaian portofolio lebih tinggi daripada warga belajar yang diberi penilaian konvensional.

5. Untuk warga belajar yang berusia di atas 15 tahun, hasil belajar membaca dan hasil belajar menulis warga belajar yang diberi penilaian portofolio lebih tinggi daripada warga belajar yang diberi penilaian konvensional.

6. Untuk warga belajar yang diberi penilaian portofolio, hasil belajar membaca dan hasil belajar menulis warga belajar yang berusia di atas 15 tahun lebih tinggi daripada warga belajar yang berusia 15 tahun ke bawah.

7. Untuk warga belajar yang diberi penilaian konvensional, hasil belajar membaca dan hasil belajar menulis warga belajar yang berusia 15 tahun ke bawah lebih tinggi daripada warga belajar yang berusia di atas 15 tahun.

\section{Implikasi}

Temuan bahwa jenis penilaian portofolio lebih tinggi dibandingkan dengan jenis penilaian konvensional dalam pembelajaran keaksaraan fungsional bagi warga belajar pada satuan pendidikan luar sekolah memberikan implikasi bahwa dalam penggunaan jenis penilaian portofolio dalam pembelajaran keaksaraan fungsional lebih tepat kiranya apabila jenis penilaian yang digunakan adalah jenis penilaian portofolio, di samping jenis penilaian konvensional yang dapat merupakan alternatif pilihan penilaian proses.

Penggunaan jenis penilaian konvensional yang selama ini digunakan pamong atau fasilitator dalam pembelajaran keaksaraan fungsional bagi warga belajar hendaknya lebih diintensifkan dalam meningkatkan hasil belajar keaksaraan fungsional yang lebih memiliki makna kemanfaatan bagi kehidupan sehari-hari mereka, khususnya dalam pengembangan pola berpikir dan bekerja dalam memenuhi kebutuhan hidupnya sehari-hari, karena ternyata jenis penilaian portofolio lebih memberikan manfaat bagi warga belajar dan sekaligus meningkatkan dorongan bekerja dan belajar keaksaraan fungsional yang sangat dirasakan kegunaannya bagi usaha dan kebutuhan hidup sehari-hari mereka dibandingkan dengan jenis penilaian konvensional seperti yang dilaksanakan di sekolah-sekolah umum.

Dengan berbagi pengalaman dan keterampilan dalam mengerjakan tugas yang harus dikumpulkan dalam bentuk portofolio, serta terjadinya interaksi atas beragam keunikan, perbedaan, dan karakteristik warga belajar menjadikan pengalaman warga belajar menjadi lebih kaya dan berpengaruh kepada pola pikir dan cara usaha mengatasi permasalahan hidupnya yang lebih efektif dan efisien.

Dalam penelitian ini ditemukan terdapat interaksi antara jenis penilaian dan kelompok usia warga belajar dalam pengaruhnya terhadap hasil belajar membaca dan hasil relajar menulis. Interaksi menunjukkan adanya perbedaan berlawanan antara jenis penilaian portofolio dan jenis penilaian konvensional terhadap hasil belajar keaksaraan fungsional apabila kelompok usia warga belajar dipertimbangkan dan ini memberikan beberapa implikasi. Pertama, penerapan jenis penilaian yang sama kepada semua warga belajar tanpa memper-timbangkan kelompok usia warga belajar merupakan keputusan yang keliru. Kedua, sekalipun kelompok usia warga belajar sudah dipertimbangkan, namun penerapan jenis penilaian yang kurang tepat juga keliru. Keputusan yang tepat dalam meningkatkan hasil belajar membaca dan hasil relajar menulis adalah apabila kelompok usia warga belajar menjadi pertimbangan dalam penerapan jenis penilaian dalam pembelajaran keaksaraan fungsional di satuan pendidikan nonformal.

\section{Saran}

Berdasarkan kesimpulan dan implikasi penelitian di atas, maka disampaikan lima buah saran atas temuan penelitian ini, sebagai berikut.

Pertama, bagi tutor di Lembaga Satuan Pendidikan Nonformal. (1) tutor keaksaraan fungsional hendaknya dipersyaratkan berkualifikasi S1 dan pernah mengikuti pelatihan-pelatihan yang sehubungan dengan keaksaraan fungsional serta mempunyai pengalaman mengajar minimal lima tahun agar dapat memberikan pelayanan pendidikan dan pengajaran kepada warga belajar secara lebih efektif; (2) penerapan 
jenis penilaian portofolio lebih tepat digunakan pada kelas di mana warga belajar dominan memiliki usia di atas 15 tahun, sedangkan pada kelas di mana warga belajar dominan memiliki usia 15 tahun ke bawah dapat digunakan salah satu jenis penilaian baik portofolio maupun konven-sional; (3) tutor keaksaraan fungsional seharusnya mengetahui karakteristik warga belajar dilihat dari tingkat usia warga belajar, mana yang lebin dominan untuk penggunaan jenis penilaian antara level usia di atas 15 tahun atau 15 tahun ke bawah. Dengan mempertimbangkan tingkat usia warga belajar, maka dapat ditentukan pilihan untuk penerapan jenis penilaian yang lebih sesuai dalam pembelajaran keaksaraan fungsional; (4) tutor hendaknya berpacu mengembang-kan diri untuk mengikuti pelatihan agar melek metode pembelajaran dan metode penilaian yang memiliki kemanfaatan yang sangat tinggi dalam memberikan pelayanan pendidikan dan pengajaran kepada warga belajar secara lebih efektif. Agar tutor menguasai strategi penilaian keaksaraan fungsional, maka penekanan pelatihan pada penggunaan jenis penilaian terhadap hasil belajar keaksaraan fungsional; dan (5) tutor sudah saatnya memanfaatkan berbagai jenis penilaian dalam pembelajaran, sehingga pembelajaran lebih bermakna karena selama proses pembelajaran telah ada motivasi yang memiliki makna meningkatkan usaha warga belajar untuk mencapai kesuksesan dalam belajarnya.

Kedua, bagi satuan pendidikan nonformal. Bagi satuan pendidikan nonformal hendaknya dapat mengadopsi inovasi dalam bidang pendidikan, khususnya dalam upaya menata kurikulum berbasis penilaian proses. Selain itu, hendaknya lebih intensif dalam upaya peningkatan kompetensi tutor baik melalui pelatihan maupun magang dalam bidang penilaian dalam pembelajaran.

Ketiga, bagi peneliti pendidikan nonformal. Penelitian yang telah dilakukan dalam studi ini, baru mengungkapkan sebagian kecil permasalahan yang berhubungan dengan jenis penilaian dalam pembelajaran keaksaraan fungsional. Dalam hal ini masih banyak lagi faktor yang dapat mempengaruhi hasil belajar keaksaraan fungsional yang belum diungkapkan dalam penelitian ini. Untuk itu disarankan kepada peneliti pendidikan nonformal yang berminat untuk melakukan kajian atau penelitian lanjut yang lebih mendalam dan komprehensif, agar upaya peningkatan kemampuan warga belajar dapat ditingkatkan dengan optimal, misalnya dengan melakukan penelitian research and development pengembangan model pembelajaran bagi warga belajar, pengembangan model pembelajaran orang dewasa yang inovatif untuk meningkatkan kemampuan berpikir dan berwirausaha sehingga kebutuhan dan cita-cita hidup mereka dapat dicapai.

\section{DAFTAR PUSTAKA}

Bloom, B.S. et al,. (1987). Taxonomy of educational objectives. Handbook 1: Cognitive domain. New York dan London: Longman Inc

Guba, E.G. \& Lincoln, Y.S. (1988). Effective evaluation. Francisco: Jossey-Bass Publishers.

Karsana. (2002). Keterampilan menulis. Jakarta: Karunia.

Pintner, R. (1970). Educational psychology. New York: A Division of Harper and Row Publisher.

Sardiman. (1986). Interaksi dan motivasi belajar mengajar. Jakarta: Rajawali Pers.

Sudjana, N. (1999). Penilaian hasil proses belajar mengajar. Bandung: Remaja Rosdakarya.
Sudjana, N. (2000). Dasar-dasar proses belajar mengajar. Bandung: PT Sinar Baru Algensindo. 2000.

Surapratana, S. \& Hatta, M. (2004). Penilaian porto-folio: Implementasi kurikulum 2004. Bandung. Remaja Roosdakarya.

Tayibnapis, F.Y. (2000). Evaluasi program. Jakarta: Rineka Cipta, 2000.

Tessmer, M. (1995). Planning and conducting formative evaluation. London: Kogan Page Limited.

Zainul, A. \& Nasoetion, N. (1997). Penilaian hasil belajar. Jakarta: P2T Universitas Terbuka Depdikbud. 